\author{
Andrzej ANTCZAK
}

Simón Bolívar University

\author{
Maria Magdalena ANTCZAK \\ Simón Bolívar University
}

Gustavo GONZALEZ HURTADO

Simón Bolívar University

Konrad A. ANTCZAK

College of William \& Mary, USA

\title{
COMMUNITY ARCHAEOLOGY IN LOS ROQUES ARCHIPELAGO NATIONAL PARK, VENEZUELA
}

ABSTRACT Convinced that archaeology as a past-oriented discipline should exert a transformative impact on the present, we discuss a series of initiatives that aim at interweaving the past of the Los Roques Archipelago, located $135 \mathrm{~km}$ off the central coast of Venezuela, into its present-day community life. Pioneering archaeological research carried out on these islands since 1982 revealed an unexpectedly rich volume of diversified artifacts and contextual information on the Amerindian seamen who seasonally exploited the local natural resources between A.D. 1200 and 1500. We are confident that despite the historical discontinuity between the pre-Hispanic seamen and the current population of the archipelago, the vibrant and colorful archaeological past will reach the present-day inhabitants, enriching their socio-cultural identity and influencing their way of life that currently oscillates entrapped between fishing and tourism-oriented activities. We discuss the aims and methodology of community archeology activities that include talks, exhibits, publications, documentary films and - above all - archaeological 
workshops that bring together the archaeologists and Los Roques schoolchildren in experiential archaeological events.

KEY WORDS Community archaeology, pre-Hispanic past, socio-cultural identity, Los Roques Archipelago, Venezuela.

\section{INTRODUCTION}

In recent years, community archaeology has undergone dynamic evolution in various socio-cultural contexts of the world. ${ }^{1}$ Despite diversity in approaches, practices and effects, community archaeology features the underlying aim of connecting past to present through direct interaction between archaeologists and local communities. The rapid growth of this phenomenon has been attributed to the central position of the "social" aspect in post-processual archaeology. ${ }^{2}$ An emphasis on diversity of interpretative perspectives as well as on social significance, social or enhanced inclusion, and heritage stewardship ${ }^{3}$ has come to figure prominently in the academy and beyond. ${ }^{4}$ Social, educational, economic and political benefits on living communities brought about by community archaeology programs have been widely recognized, though controversies remain about the methods of critical evaluation of these benefits and the degree of attainment of community archaeology project goals s. Despite such con-

B.J. Little, 'Archaeology as Shared Vision' in eadem (ed.), Public Benefits of Archaeology, Gainesville 2002, pp. 3-19; Y. Marshall, 'What is community archaeology?' World Archaeology, Vol. 34, № 2 (2002), pp. 211-219; eadem, 'Community Archaeology' in B. Cunliffe, Ch. Gosden, R.A. Joyce (eds.), The Oxford Handbook of Archaeology, Oxford 2009, pp. 1078-1102; L. Derry, M. Malloy, Archaeologists and Local Communities, Washington, D.C. 2003; I. Hodder, 'Archaeological Reflexivity and the "local" Voice', Anthropological Quarterly, Vol. 76, № 1 (2003), pp. 55-69; N. Merriman, Public Archaeology, London 2004; Ch. Damm, 'Archaeology, Ethnohistory and Oral Traditions: Approaches to the Indigenous Past', Norwegian Archaeological Review, Vol. 38, № 2 (2005), pp. 73-87; G. Tully, 'Community archaeology: general methods and standards of practice’, Public Archaeology, Vol. 6, № 3 (2007), pp. 155-187; F. Simpson, 'Community Archaeology under Scrutiny', Conservation and Management of Archaeological Sites, Vol. 10, № 1 (2008), pp. 3-16; S. Chirikure, G. Pwiti, 'Community Involvement in Archaeology and Cultural Heritage Management: An Assessment from Case Studies in Southern Africa and Elsewhere', Current Anthropology, Vol. 49, № 3 (2008), pp. 467-485; Y. Paz, 'Community Archaeology in Proto-Historical Tel Bareqet, Israel: School Children and Agency for Active Public Engagement in Cultural Heritage Projects', Public Archaeology, Vol. 9, № 1 (2010), pp. 34-47; M.J. Stottman (ed.), Archaeologists as Activists. Can Archaeologists Change the World?, Tuscaloosa 2010; S. Atalay, Community-Based Archaeology. Research with, by, and for Indigenous and Local Communities, Berkeley-Los Angeles 2012.

2 I. Hodder, 'The "Social" in Archaeological Theory: An Historical and Contemporary Perspective' in L. Meskell, R.W. Preucel (eds.), A Companion to Social Archaeology, Oxford 2004; F. Simpson, 'Community...'

3 I. Marshall, 'Community..., p. 1083.

$4 \quad$ G. Tully, 'Community...', p. 158.

$5 \quad$ F. Simpson, 'Community...'; F. Simpson, H. Williams, 'Evaluating Community Archaeology in the UK', Public Archaeology, Vol. 7, № 2 (2008), pp. 69-90; Y. Paz, 'Community.... 
troversies, community archaeology may prove vital to the very survival of archaeology itself, according to some. ${ }^{6}$

Archaeology in Venezuela, since its debut as a scholarly discipline in the 1950s, has not been "spoiled", so to speak, by governments or private interests wielding agendas and funding. In the meantime, general public understanding of the purposes, needs and achievements of archeology has remained minimal. The reasons for this state of affairs appear amply and variously in the theoretical perspectives of Rafael Gassón and Erika Wagner, Iraida Vargas, Emanuel Amodio, Natalia Diaz, Lorenzo González and Orlando Marín, Mario Sanoja, and Lino Meneses and Gladys Gordones,7 among others. The socio-political changes occurring in Venezuela during the past decade promoted projects related to valorization of cultural heritage in which emphasis was placed on local community involvement (see the official website of the Instituto del Patrimonio Cultural). ${ }^{8}$ What remains to be critically evaluated is the correlation between the goals and effects these initiatives have had on targeted communities in such areas as efficiency in local heritage conservation and management, effectiveness of dialogue between professionals and community members, and improvement in the economic condition of local residents. The results of some archaeology community projects with longer track records have already been critically evaluated. ${ }^{9}$

The purpose of this paper is not a critical analysis of such issues. However, we would like to point out that good examples of linking "archaeology from above" with "archaeology from below" 10 are still too few partly because, in our understanding, archaeologists and heritage managers are unwilling to truly cede some of their pow-

6 Y. Marshall, 'What..., p. 218; P.A. Young, 'The Archaeologist as Storyteller' in B.J. Little (ed.), Public Benefits of Archaeology, Gainesville 2002, p. 240; S. Atalay, Community-Based..., p. 3; see also P.L. Jeppson, G. Brauer, 'Hey, Did You Hear about the Teacher Who Took the Class Out to Dig a Site? Some Common Misconceptions about Archaeology in Schools' in L. Derry, M. Malloy (eds.), Archaeologists and Local Communities. Partners in Exploring the Past, Washington 2003, p. 90.

7 R. Gassón, E. Wagner, 'Los otros Vestigios de la Atlántida, o el surgimiento de la arqueología moderna en Venezuela y sus consecuencias' in Y. Freites, Y. Texera (eds.), Tiempos de Cambio. La ciencia en Venezuela 1936-1948, Caracas 1992; I. Vargas Arenas, 'Introducción al Estudio de las Ideas Antropológicas Venezolanas 1880-1936', Semestre Histórico, № 3 (1976), pp. 151-175; eadem, Historia, identidad y poder, Caracas 1992; E. Amodio (ed.), Historias de la antropología en Venezuela, Maracaibo 1998; N. Díaz Peña, La colección arqueológica del Lago de Valencia: documentación y nueva museología, Valencia 2006; L. González Casas, O. Marín, 'Tiempos superpuestos: arquitectura moderna e "indigenismo” en obras emblemáticas de la Caracas de 1950', Apuntes, Vol. 21, № 2 (2008), pp. 252-265; M. Sanoja Obediente, I. Vargas Arenas, La Revolución Bolivariana. Historia, Cultura y Socialismo, Caracas 2008; L. Meneses Pacheco, G. Gordones Rojas (eds.), La arqueología venezolana del nuevo milenio, Mérida 2001; iidem, De la Arqueología en Venezuela y de las Colecciones Arqueológicas Venezolanas: Propuesta para la construcción de la Red de Museos de Historia de Venezuela, Caracas 2010.

8 <http://www.ipc.gob.ve/ipc>, 29 October 2012; see also Y. Morales Hidalgo, La Conservación Integral del Patrimonio Cultural Construido del Oriente Venezolano, Unpublished Doctoral Thesis, Universidad Central de Venezuela, Caracas 2011.

9 See for example Y. Altez, P. Rivas, Arqueología e historia de la parroquia Caruao, Caracas 2001; H. Cardona Machado, 'Viejos Conceptos para un Nuevo Contexto: Aportes desde la Arqueología en Comunidades de la Costa Central Venezolana', Antipoda, Vol. 14 (2012), pp. 185-208.

10 N. Faulkner, 'Archaeology from below', Public Archaeology, Vol. 1, № 1 (2000), pp. 21-33. 
ers to local people. ${ }^{11}$ For example, archaeologists still maintain hegemonic claims on the past and stigmatize amateurs, equating them with looters and traffickers of antiquities. Contributions to archaeology made by contemporary non-archaeologists - if any at all of such are taken into consideration by archaeologists - are not judged fairly on their merits and faults. ${ }^{12}$ The majority of archaeological sites are still disconnected from the local living landscapes. Finally, a willful deafness regarding their results on both sides of the argument: on the one hand, local versions of the past are either unappreciated or completely ignored by archaeologists; and on the other, academically produced narratives of that same past remain unknown to the majority of local communities.

While we agree with the ideal of "democratic archaeology" promoting diversification of the voices, activities and responsibilities involved in working with the past, ${ }^{13}$ it nevertheless becomes evident that narratives and activities coming from the academy cannot be absent from local contexts. If archaeological finds are not available to all members of society, then the interpretation of such evidence - and the past in general becomes distorted. ${ }^{14}$ We are convinced that archaeologists in Venezuela should neither wait for the media to popularize their achievements among the general public nor wait for their field to sufficiently enter formal educational curricula (meanwhile however, they should participate in promoting the latter end). Waiting is not worthwhile, if for no other reason than the fact that the media, even once finally interested, often sensationalizes and creates misconceptions about archaeology. ${ }^{15}$ For its part, the dominant power often distorts the past for its own political and ideological purposes. ${ }^{16}$ Such "distortions" may perturb relations between archaeologists and local residents, relations which in any case are often not easy.

Instead, archaeologists should find ways to reach out to localities and engage with non-archaeologists in order to meet the general public's educational, social and cultural needs through stimulating the reinterpretation of archaeological resources by local people. ${ }^{17}$ In this way, local groups will be able to own the past archaeologists discover or rather create, as post-processualism maintains. ${ }^{18}$ In addition, via this approach, academic archaeology becomes empowered to release its potentially trans-

11 See S. Chirikure, G. Pwiti, 'Community...’, p. 474.

12 But see A. Antczak, M.M. Antczak, Los Mensajes Confiados a la Roca, Caracas 2007.

13 See G. Tully, 'Community...'; S. Atalay, Community-Based..., pp. 79-80.

14 P.G. Stone, 'Presenting the Past: A Framework for Discussion' in J.H. Jameson Jr. (ed.), Presenting Archaeology to the Public. Digging for Truths, Lanham 1997, p. 27.

15 Ibid., p. 28; P.L.Jeppson, G. Brauer, 'Hey...', p. 84; G. Wallace, 'Archaeology and Society' in R.A. Bentley, H.D.G. Maschner, Ch. Chippindale (eds.), Handbook of Archaeological Theories, Lanham 2009, p. 400; see also P.P. Funari, A.N. Vieira de Oliveira, E. Tamanini, 'Archaeology to the Lay Public in Brazil: Three Experiences' in J.H. Jameson Jr., and S. Baugher (eds.), Past Meets Present: Archaeologists Partnering with Museum Curators, Teachers and Community Groups, New York 2007, p. 226.

16 N. Faulkner, 'Archaeology...'; S. Chirikure, G. Pwiti, 'Community...’, p. 476.

17 N. Merriman, Public..., p. 7.

18 Y. Marshall, 'What ..., p. 218. 
formative power to local people. Furthermore, there are the benefits that may accrue to the discipline of archaeology itself from such interactions. In sum, archaeology needs to expand the scope of its principles to include the broader civic responsibility [so that] we can improve communities through archaeology and improve archaeology through communities. ${ }^{19}$

The purpose of this paper, consequently, is to discuss the gains and difficulties of the community archaeology project developed in Los Roques Archipelago National Park in Venezuela by focusing on a series of archaeological workshops in which the participants are schoolchildren. These activities originated in and are integrally linked to the Venezuelan Island Archaeology Research Project initiated in 1982 by the first two authors of this paper. We believe that once the unexpectedly rich archaeological past revealed by the research is proactively intertwined with the current realities of Los Roques community members, the latter will exploit this past in multiple tangible and intangible ways according to their needs and interests. Next, we take a step back and discuss the geographical and social-cultural setting of the Los Roques community archaeology project: its historical evolution, philosophical grounding and methodology. Finally, we conclude with reflections that may be of use to similar future initiatives in Venezuela and beyond.

\section{THE VENEZUELAN ISLAND ARCHAEOLOGY PROJECT}

As noted above, in 1982 the first two authors of this article created The Venezuelan Island Archaeology Project: a long-term, large-scale, multidisciplinary and multi-period (spanning the pre-Hispanic, colonial and republican periods) research enterprise incorporating archaeological surveys and excavations on the majority of the off-shore and inshore islands of the Venezuelan Caribbean. Before the project began, only one report about the archaeology of the above-mentioned islands was available. It was published in the 1950s as a result of a small-scale excavation carried out by a group of naturalists. ${ }^{20}$ Between 1983 and 2011, nearly 70 excavating seasons were undertaken, 62 islands surveyed, and 45 pre-Hispanic and 15 colonial sites located. Systematic excavations have been carried out at 12 sites.

The initial overarching goal of the research project was to generate, from the island perspective, hypotheses concerning the nature, dynamics and chronology of the spread of the bearers of Amerindian pottery not only from the mainland coast to the islands but from inland regions to the coast. As time passed, the research embraced a wide range of topics including settlement patterns, physical-chemical analysis of pottery, zooarchaeology, pre-Hispanic economy, historical ecology, representational material culture, and

19 P.L. Jeppson, G. Brauer, 'Hey..., pp. 79-80; see also Ch. Damm, 'Comments on S. Chirikure and G. Pwiti (2008). Community Involvement in Archaeology and Cultural Heritage Management: An Assessment from Case Studies in Southern Africa and Elsewhere', Current Anthropology, Vol. 49, № 3 (2008), p. 477.

20 Sociedad de Ciencias Naturales La Salle, El Archipiélago Los Roques y La Orchila, Caracas 1956. 
collection studies. ${ }^{21}$ The project has generated a large corpus of scientific and popular publications, conference papers, dissertations, exhibitions, and documentary films. It has also served as the inspiration for thematic international symposia. ${ }^{22}$ Currently, all the materials gathered during the project are under the curatorship of the authors and in part made available to the public at the Unidad de Estudios Arqueológicos (UEA) at the Universidad Simón Bolívar in Caracas (USB).

\section{THE LOS ROQUES ARCHIPELAGO AND ITS COMMUNITY}

The Los Roques Archipelago is located more than $135 \mathrm{~km}$ north of the central Venezuelan coast (Figure 1). A complex of coral reefs and cays established on a submarine platform of igneous-metamorphic rock, it measures $36.6 \mathrm{~km}$ from east to west and $24.6 \mathrm{~km}$ from north to south. ${ }^{23}$ Peaks rising from the rocky submarine base appear only in the form of Gran Roque Island which features a chain of hills up to 120 meters above sea level. ${ }^{24}$ There are in addition over 40 small, low and sandy islands (covered by grasses and bordered by mangroves) protected by reefs and circling a great inner lagoon of ca. $400 \mathrm{~km}^{2}$. To the east and south the submarine platform falls abruptly to a depth of $1,000 \mathrm{~m} .{ }^{25}$

The permanent settling of the archipelago by Venezuelans dates back to the beginnings of the 20th century. ${ }^{26}$ Since then, the Los Roques community has consisted of permanent residents confined to settlements on Gran Roque and Krasky Islands as well

21 A. Antczak, 'La pesca Prehispánica; El caso del sitio Dos Mosquises, Archipiélago de Los Roques, Venezuela', Proceedings of the 14th International Congress for Caribbean Archaeology, Barbados 1993, pp. 504-518; A. Antczak, Late Prehistoric Economy and Society of the Islands off the Coast of Venezuela. A Contextual Interpretation of the Non-Ceramic Evidence, Unpublished PhD Thesis, Institute of Archaeology, University College London, London 1999; M.M. Antczak, A. Antczak, 'Distribution des établissements préhistoriques dans certaines íles du Vénézuéla in Civilisations Precolombiennes de la Caraïbe', Paris 1989; A. Antczak, M.M. Antczak, 'La Esfera de Interacción Valencioide' in M.G. Arroyo, L. Blanco, E. Wagner (eds.), El Arte Prehispánico de Venezuela, Caracas 1999; M.M. Antczak, A. Antczak, Los Ídolos de las Islas Prometidas. Arqueología Prehispánica del Archipiélago de Los Roques, Caracas 2006; M.M. Antczak, A. Antczak, 'Their World in Clay: The Art of Pre-Hispanic Venezuela' in G. Griffin, M.M. Antczak, A. Antczak, S. Berti (eds.), Ancient American Art. Masterworks of the Pre-Columbian Era, 3500 BC-1532 AD, Milano 2011; L. Sajo-Bohus, M.M. Antczak, E.D. Greaves, A. Antczak, J. Bermúdez, Zs. Kasztovszky, T. Poirier, A. Simonits, 'Incipient archaeometry in Venezuela: Provenance study of pre-Hispanic pottery figurines', Journal of Radioanalytical and Nuclear Chemistry, Vol. 265, № 2 (2005), pp. 247-256; L. Sajo-Bojus, M.M. Antczak, Zs. Kasztovszky, E.D. Greaves, A. Antczak, A. Simonits, D. Palacios, B. Millán, 'Neutron Activation Analysis of Pre-Columbian Pottery in Venezuela', Journal of Physics, Vol. 41 (2006), pp. 408-416.

22 See <http://www.arqueologiausb.org>, 28 October 2012.

23 W. Williams Trujillo, Las Maravillosas Islas Venezolanas, Caracas 1980.

24 M.A. Vila, Aspectos Geopoliticos de las Dependencias Federales, Caracas 1967.

25 J. Méndez Baamonde, 'Aspectos de la geología marina en el Archipiélago de Los Roques', Memorias V Congreso Geológico Venezolano, Caracas 1977, pp. 195-225.

26 M.M. Antczak, A. Antczak, 'La historia postcolombina de Los Roques: siglos 16-19', Tópicos, № 566 (1986), pp. 14-19; M.M. Antczak, A. Antczak, 'Este faro sí era un faro bueno: El rescate del faro de la isla del Gran Roque', Tópicos, № 589 (1988), pp. 20-23. 
as temporary fishermen who have occupied various small cays, especially during lobster season. In the 1960s, the Los Roques Archipelago became an important provider of lobsters, queen conch and turtles for both the national and international markets. ${ }^{27}$ At about the same time a group of naturalists from Caracas founded the Los Roques Scientific Foundation. Operating from the Marine Biology Station on Dos Mosquises Island ${ }^{28}$ the Foundation initiated systematic research on biology, ecology and the local fishery resource.

In 1972, Los Roques became the first marine national park in Venezuela. That same year, the capture of turtles was ended: a prohibition extended in 1982 to the queen conch fishery. ${ }^{29}$ The decade of the 1990s saw the rapid development of the Los Roques tourism industry. Posadas (small often family-run hostels or inns) multiplied to serve tourists arriving daily by air from Venezuela and overseas onto the Gran Roque Island landing strip. The major changes effected by the tourism boom can in part be seen today in the considerable mix of nationalities and ethnicities, political and religious affiliations, socio-economic strata, professional occupations, and finally values and interests of the residents. In many ways the small fishermen's village of Gran Roque Island had evolved into a cosmopolitan community by the end of the 1990s. The divisions, differences, contradictions and even tensions in the life of the present-day community that have arisen over differences in value systems are poorly reflected in scholarly literature. The particulars of changes in community values and in the construction of the identity of the roqueño over time remain to be studied from sociological and anthropological perspectives. As has been realized by scholars utilizing community archaeology in different geographical and socio-cultural contexts of the world, conflicting, competing and dynamically changing interests within communities are not easily harmonized around the past..$^{30}$ But doing that work is worth the effort.

In 1987, the population of the Los Roques Archipelago was 807: 586 resided on Gran Roque Island and 221 were temporary fishermen mainly from Margarita Island. ${ }^{31}$ By 2012 the number had risen to ca 1,500 residents including 353 primary and secondary school students. ${ }^{32}$ The roqueños are not direct descendants of the Amerindian com-

27 J. Posada, B. Álvarez, J. González, 'Análisis del sistema pesquero del Parque Nacional Archipiélago de Los Roques', Memorias del Congreso Iberoamericano y del Caribe, Porlamar 1988.

28 M.M. Antczak, A. Antczak, 'Las investigaciones arqueológicas en el Parque Nacional Archipiélago de Los Roques' in T. Amend, A. Antczak, M.J. Antczak, R.H. Delgado, J. Guada, B. Rodríguez, P. Vernet (eds.), Parque Nacional Archipiélago de Los Roques, Caracas 1992, pp. 43-51.

29 J. Buitrago, 'Attempts to protect hawksbills in a Venezuelan National Park', Marine Turtle Newsletter, № 14 (1980), pp. 4-5; A. Antczak, J.M. Posada, M.M. Antczak, R. Cipriani, D. Schapira, I. Montaño, 'Early Human Impact on Queen Conch (Strombus gigas) in Venezuela' in A. Antczak, R. Cipriani (eds.), Early Human Impact on Megamolluscs, Oxford 2008, pp. 49-64.

30 See S. Chirikure, G. Pwiti, 'Community...'; see also H. Silverman (ed.), Archaeological Site Museums in Latin America, Gainesville 2006.

31 T. Amend, A. Antczak, M.M. Antczak, J.R. Delgado, H.J. Guada, B. Rodríguez, P. Vernet, Parque Nacional Archipiélago Los Roques, Caracas 1992, p. 9.

32 M. Zulay Barrios (director of the local school on Gran Roque Island), personal communication, September 2012. 
munities which, according to the results of archaeological research, seasonally occupied the archipelago in the pre-Hispanic past. While those groups visited the islands from the north-central Venezuelan mainland between A.D. 1200 and 1500, the ancestors of the roqueños who settled the islands by the beginning of the 20th century came mainly from the island of Margarita to the east.

\section{THE GENESIS OF LOS ROQUES ARCHAEOLOGY AS A LONG-TERM COMMITMENT}

The following section traces the development of the Los Roques community archaeology case study alongside the main developmental stages of its research mother-project. The discussion below is informed by the methodologies employed in community archaeology projects developed in different parts of the world..$^{33}$

Beginning their archaeological research in 1982 the first two authors, originally trained as ethnographers, brought to Los Roques the methods and experiences of ethnographic "participant observation" gained through interaction with remote rural communities in Poland. Raised in the European intellectual tradition which forges a strong alliance between history and archaeology, ${ }^{34}$ the authors viewed their Los Roques research as a long-term commitment to study not only the archaeology but the history, environment and lives of the present-day residents. They also stressed the importance of a reflexive "being on the islands", i.e., wide-ranging on-island dialogue with local people, maintaining of fieldwork diaries as research progressed, and increasing awareness of self-positioning in the local social, cultural and political contexts. Meanwhile, artifacts in context - that is, not only the objects themselves but their spatial relationships to one another in situ - were "interviewed" as if they were the archaeological equivalents of native informants. ${ }^{35}$ Therefore, it may be said that the authors constituted typical "cultural outsiders with a long-term commitment" ${ }^{36}$ in the Los Roques context. The nature of their research background was crucial to their early realization that archaeological sites should be approached as valuable and still-living entities, and that the research itself should value relationships with the local people as much as the archae-

33 See compilation by Y. Marshall, 'Community..., pp. 1083-1086; see also S. Moser, D. Glazier, J.E. Phillips, L. Nasser el Nemr, S. Mousa, M. Nasr Aiesh, R.S. Richardson, A. Conner, M. Seymour, 'Transforming archaeology through practice: strategies for collaborative archaeology and the community project at Quseir, Egypt', World Archaeology, Vol. 34 (2002), pp. 220-248; B. Mapunda, P. Lane, 'Archaeology for Whose Interest - Archaeologists or the Locals?' in N. Merriman (ed.), Public Archaeology, London 2004; G. Tully, 'Community...'; Y. Paz, 'Community....

34 See for example the synthesis in R. Bernbeck, S. Pollock, 'The Political Economy of Archaeological Practice and the Production of Heritage in the Middle East' in L. Meskell, R.W. Preucel (eds.), A Companion to Social Archaeology, Oxford 2007, p. 338.

35 See I. Hodder, 'Archaeological..., p. 62.

36 Ch.Damm, 'Towards a Glocal Archaeology?', Reply to Comments on Ch. Damm (2005): 'Archaeology, Ethnohistory, and Oral Traditions: Approaches to the Indigenous Past', Norwegian Archaeological Review, Vol. 39, № 1 (2006), p. 76. 
ological materials encountered. ${ }^{37}$ The authors soon complemented the ethnographic background with which they had arrived with studies in anthropology and archaeology at the Universidad Central de Venezuela and, later, with doctoral studies in prehistoric archaeology at University College, London.

Their experience with Los Roques proceeded through two main phases featuring approaches and activities designed to advance two aims: research and community engagement. The authors endeavored, meanwhile, to coordinate their Los Roques progress with scholarly and science-popularizing activity in Caracas. On the research level, the 1980s and early 1990s saw intense archaeological surveys and large-scale systematic excavations carried out in vast, remote, largely uninhabited and archaeologically unexplored areas under often extreme life and work conditions. The research approach in this period may be considered a blend of historical-cultural and processual tendencies; but the excavations themselves were decidedly contextually and even microcontextually-oriented..$^{38}$ The early research questions about the island inhabitants were embodied in the title of the Los Roques archaeology exhibit organized by the authors in the Museo de Arte La Rinconada (Caracas) from 1983 to 1987: Who were they? Where did they come from? Where did they go? ${ }^{39}$

Regarding Los Roques community engagement, the archaeologists employed some stationary ethnographic fieldwork methods: they lived with the fishermen in their rancherias or rustic huts and accompanied them in their chores, establishing relationships and slowly gaining knowledge of the particularities of that insular world. This approach was essential to the success of the project. The fishermen proved not only irreplaceable guides and masters of navigation amongst the thousands of coral reefs; not only connoisseurs of tides, currents, winds and marine creatures; they also knew many environmental details of key importance in the identification of archaeological sites. Because some field campaigns were up to four months long, day-to-day collaboration and conviviality with the fishermen developed into long-lasting friendships, mutual respect and trust.

During the 1980s while surveys were performed on over 40 islands of the archipelago, communication and interaction with the temporary occupants of the small cays (including Krasky Island) were much more personal and frequent than with the permanent inhabitants of the village on Gran Roque. As a result, relationships with Gran Roque residents (with some exceptions) did not develop on the same basis of mutual trust as with the temporary fishermen. Another circumstance relating to the "disconnection" with Gran Roque residents was that the headquarters of the project were established at the Dos Mosquises Biology Station situated on an island distant from Gran Roque but close to the temporary rancherias on La Pelona, Domusky Norte, Cayo Sal, Carenero and Fernando Islands (some of these islands are no longer inhabited) (Figure 1). After 2000, interactions between the archaeologists and

37 F. Simpson, 'Community..., p. 14; Y. Marshall, ‘Community..., p. 1078.

38 M.M. Antczak, A. Antczak, Los Ídolos...

39 See <http://www.arqueologiausb.org>, 28 October 2012. 
the seasonal fishermen weakened while relationships with Gran Roque villagers strengthened (see below).

The long-term collaboration with the seasonal fishermen was crucial not only for our archaeological survey logistics but for gaining an understanding of both the physi$\mathrm{cal}$ and cultural environment of the area. It was also crucial for expanding the context of interpretation of the pre-Hispanic past as well as for building up a collection of modern fish bones and otoliths used for the identification of the zooarchaeological specimens. Observing and participating in daily life at the campsites widened the range of research questions the archaeologists posed to the archaeological record; it also influenced their reconstruction of pre-Hispanic campsite social contexts. ${ }^{40}$

During that same period in Caracas, the archaeologists led a series of initiatives aimed at popularizing their work on the islands through organized school visits with pottery replica-making workshops, lab tours, talks, exhibits and documentary films. Among the popularizing archaeology publications figure a series of 18 profusely illustrated articles about various subjects of the research. These appeared in several thousand printed copies of the journal Tópicos which were distributed free of charge. ${ }^{41}$ The authors also wrote texts on archaeology and the pre-Hispanic past of the Venezuelan islands for a primary education handbook. ${ }^{42}$

During the latter half of the 1990s, the authors were mostly absent from the Los Roques scene while pursuing their doctoral studies in London. Academically, the time had come to reach for the goal extant since the 1980s: making sense of almost $400 \mathrm{hu}-$ man pottery figurines recovered from pre-Hispanic Los Roques campsites. Supported by an enormous corpus of data gathered in contextually-oriented excavations, we were faced with the necessity of evolving an appropriate and distinct theoretical and methodological approach capable of reconstructing the social context of the figurines' use and then their abandonment on the islands (although they were produced on the mainland). This approach proved to be crucial in the reconstruction of the figurines' social realities. ${ }^{43}$

The second period of the archaeologists' commitment to Los Roques began with their return to the islands in early 2000 . The focus of their activities now changed from local community member involvement in fieldwork to activities benefiting the community. One of the first gains of this period was the installation of an archaeological stopover facility on Dos Mosquises Island. Funded by an international cooperation agency, this hardwood, stainless steel and tempered glass installation was situated at the very edge of this island's archaeological site. It featured a permanent exhibition of texts

40 M.M. Antczak, A. Antczak, Los Ídolos...

41 See <http://www.arqueologiausb.org>, 28 October 2012.

42 M.M. Antczak, A. Antczak, 'La Arqueología y los Arqueólogos; Los Aborígenes de las Islas Venezolanas' in A. Ojeda, P.G. Martínez (eds.), Educación Artística, $7^{0}$ Grado, Tercera Etapa, Educación Básica, Caracas 1988, pp. 130-132.

43 A. Antczak, Late...; M.M. Antczak, 'Idols' in Exile. Making Sense of Prehistoric Human Pottery Figurines from Dos Mosquises Island, Los Roques Archipelago, Venezuela, Unpublished PhD Thesis, Institute of Archaeology, University College London, London 2000. 
in Spanish and English as well as drawings and photographs dedicated to Los Roques pre-Hispanic archaeology entitled "The Stopover for Information and Reflection: The Sacred Island of Pre-Hispanic Venezuela". Benches placed on the sand inside stimulate the visitor to reflect on how the past influences both the present and future of people today. The site was inaugurated in 2002 with a full day of socio-educational activities designed for schoolchildren, teachers and representatives of parents from the Gran Roque village.

Between 2002 and 2005, USB archaeologists and marine biologists working together carried out a large project on pre-Hispanic and modern queen conch megamiddens. ${ }^{44}$ This provided another opportunity for scholars and locals to interact, though it still constituted archaeology "from above". Noteworthy however is that one aspect of this project, the documentary film "El Mensaje de la Especie" ("The Voice of the Species"; see www.arqueologiausb.org) included several interviews with Los Roques fishermen. The project as a whole benefited significantly from their knowledge and experience. This film was publicly presented on the central square of Gran Roque village.

Beginning in the year 2000, the archaeologists' relationships with seasonal fishermen waned while those with Gran Roque village inhabitants increased rapidly. Socio-educational activities focusing on the Gran Roque community came to the fore since the islands had already been largely researched from the archaeological perspective. Three factors pushed our shift from fishermen to inhabitants. First, navigation from Gran Roque to the distant islands of the archipelago is dangerous after dark, so temporary fishermen could rarely participate in afternoon activities. Second, their daily work routines mandated different schedules, objectives, and priorities than the largely tourism-oriented life of the Gran Roque villagers. Finally, the two groups' interest in the schoolchildren-based activities differed. The village featured complete families while wives and children of the fishermen resided mainly on Margarita Island and the mainland coast.

The early 2000s saw the first two authors introducing archaeology-related lectures into the USB curriculum, followed by creating the UEA (Archaeology Research Unit) on campus in 2005. This academic platform facilitated recruitment and incorporation of university students into the Los Roques community archaeology projects. Since that time, the last two listed authors of this paper became an integral part of the Los Roques community archaeology team. Various other students participated in the activities intermittently. The UEA staff contributes to the community archaeology team with expertise in anthropology and archaeology, management of hospitality, environmental sustainability, community development and archaeometry. Among close collaborators

44 A. Antczak, M.M. Antczak, 'Pre-Hispanic Fishery of the Queen Conch, Strombus gigas, on the Islands off the Coast of Venezuela' in P. Miloslavich, E. Klein (eds.), Caribbean Marine Biodiversity. The Known and the Unknown, Lancaster 2005; A. Antczak, R. Cipriani (eds.), Early Human Impact on Megamolluscs, Oxford 2008; see also J.M. Posada, A.W. Stoner, K. Sullivan Sealey, A. Antczak, D. Schapira, R. Torres, I. Montano, M. Ray Culp, D. Aldana Aranda, Regional Initiative for the Evaluation of Queen Conch (Strombus gigas) Exploitation under an Historical Perspective, paper presented at the 59th GCFI Institute Conference, Belize City 2006. 
of the UEA are sociologists, marine biologists and ecologists. Such multidisciplinarity aids in interfacing with the complex cultural, social, economic, political and environmental realities of Los Roques Archipelago National Park. ${ }^{45}$

In 2004, the exhibition El Refugio para el Pasado: Los Arquitectos y los Arqueólogos Soñando Juntos (The Refuge for the Past: Archaeologists and Architects Dreaming Together) was opened at the Galeria de Arte Nacional in Caracas. Though the exhibition did not involve the Los Roques community directly, the latter was interwoven. This exhibition was the result of sustained interdisciplinary cooperation between archaeologists and both professors and students of the Department of Architecture at USB. The exhibit included some Los Roques pre-Hispanic artifacts, a selection of archaeological drawings, original field notes, maquettes and plans for a future ecomuseum envisioned by the archaeologists for the Los Roques community, plus scale models of a fisherman's hut and other associated constructions. Exercises with architecture students continued with designs for the projected anthropology and archaeology museum at USB and of the museum on Gran Roque Island. One of the undergraduate theses addressing the Los Roques museum project was personally presented to the Gran Roque community by its author. ${ }^{46}$ It should be added that the creation of the Los Roques community museum, local heritage center or ecomuseum (three ways of thinking of one facility) - an early dream of the first two authors - received a strong push from discussions they held in the 1990s with Chris Hudson, designer of the site museum at Agua Blanca in Ecuador. ${ }^{47}$ "Focusing Pride in the Past", the title of the original article by Chris Hudson and Colin McEwan describing their 1987 Agua Blanca initiative, ${ }^{48}$ was adapted as Orgullo por el Pasado. It has been used since then as a motto for the Los Roques community archaeology project.

The preliminary ideas for the Los Roques museum were proposed by the first two authors at the public meeting of the Autoridad Única de Area del Parque Nacional Archipiélago Los Roques (Authority for the Los Roques Archipelago National Park Area, a supervising governmental body) in 1993. The authors continued to discuss the creation of the museum throughout 2001 in a series of meetings with said authority, together with representatives of the Instituto del Patrimonio Cultural (Cultural Heritage Institute), Galeria del Arte Nacional (National Art Gallery) and the Vice-Ministry of Culture. The authors also discussed their ideas with the Gran Roque community in a series of meetings spanning 2007-2010, especially during the Jornadas de Valoración

45 G. González Hurtado, Prioridades de investigación orientadas a mejorar la gestión ambiental del Parque Nacional Archipiélago Los Roques (PNALR), Unpublished Masters Thesis, Universidad Simón Bolívar, Caracas 2007.

46 G. Bosio, Ecomuseo del Hombre Roqueño para la Isla Gran Roque, Unpublished Undergraduate Thesis, Universidad Simón Bolívar, Caracas 2008.

47 C. McEwan, M.I. Silva, Ch. Hudson, 'Using Past to Forge the Future: The Genesis of the Community Site Museum at Agua Blanca, Ecuador' in H. Silverman (ed.), Archaeological Site Museums in Latin America, Gainesville 2006.

48 Ch. Hudson, C. McEwan, 'Focusing Pride in the Past: Agua Blanca, Ecuador', Museum, Vol. 154, № 2 (1987), pp. 125-128. 
de Patrimonio Histórico-Cultural de Los Roques (Workshop on the Appreciation of Local Historical-Cultural Heritage).

The publication in 2006 of the 640-page volume Los Ídolos de las Islas Prometidas: Arqueología Prehispánica del Archipiélago de Los Roques ${ }^{49}$ was enthusiastically received by the Los Roques community. Sponsored by the largest Venezuelan private bank, the book was formally "baptized" (the custom in Venezuela) in the cultural center of Gran Roque village with the participation of inhabitants and local authorities. The book soon became an obligatory reference for professionals, students and amateurs interested in the archeology of Los Roques and the entire north-central Venezuelan region. Although the book is a rigorous scientific treatise, it is interesting to note that the last of its more than 1,500 illustrations depicts Pablo Mata, a roqueño fisherman. The archipelago attracted him - as it did pre-Hispanic Amerindians - with its abundant natural resources. It then marked him indelibly, as it did them.

The first two authors began a series of talks on archaeology-related topics (organized by the Fundación Científica Los Roques) to Gran Roque schoolchildren in 2007. That same year the First Archaeology Workshop for such schoolchildren was held, and others followed in 2009, 2011 and 2012 (see following section for details). In 2009 USB was the site of the three-day Workshop for Multipliers of Historical-Cultural Heritage of the Los Roques Archipelago. In addition to sessions dedicated to pre-Hispanic, colonial and republican archaeology of the islands, the workshop invited speakers who addressed the relationships between historical heritage and tourism. This workshop was well-attended by representatives of the Los Roques community as well as participants from various regions of the country. That same year, representatives of the schoolchildren who participated in the first workshop in Boca de Sebastopol came to USB for three days to participate in the daily activities of the archaeological lab. They worked with the materials they themselves had previously excavated. In 2009, the archaeologists held a series of conferences in Gran Roque village tailored to schoolchildren, local authorities and the general public. A five-day Workshop on the Appreciation of Local Historical-Cultural Heritage took place on Gran Roque Island (designed especially for tourism operators) that year also. Perhaps one of the main results of this workshop was the fact that the community expressed the necessity for the creation of a local museum and proposed the conformation of a local social organization to promote its materialization. Encouraged by these prospects the UEA team maintained a series of meetings with a highly diverse (in a cultural, social and political sense) group of community members, but the continuity of this initiative was temporarily suspended due to lack of sponsorship.

The majority of the above activities were directed at the adult social actors of the Los Roques Archipelago. We shared the results of our research with them and discussed concrete ways the past could be used to improve their lives in the present. Below, we turn to a series of archaeology workshops featuring proactive outreach to Los Roques schoolchildren.

49 M.M. Antczak, A. Antczak, Los Ídolos... 


\section{THE LOS ROQUES ARCHAEOLOGY WORKSHOPS}

The schoolchildren became our favorite partners in the Los Roques community archaeology project. We agree with Patrice Jeppson and George Brauer, leaders of the Baltimore County Public School's Archaeology Program, that Schools are one of the main means of intergenerational transmission of culture in our society and (...) education structures everyday beliefs and expectations for most citizens. ${ }^{50}$ We also align ourselves with Yitzhak Paz who, on the basis of a community archaeology project in Tel Bareqet, Israel dedicated to schoolchildren, concluded that children are natural leaders of change towards a multi-voiced interpretation of local cultural heritage. ${ }^{51}$

Our workshops for Los Roques school-age children center on archaeological excavation. They emphasize group activity and interpretive processes through on-site and hands-on experience with authentic "things" from the past. The workshops provide much more than site interpretation with access to epistemology and people who use this epistemology. ${ }^{52}$ They add experiential archaeology. This coheres with our understanding of the archaeological discipline as a process, a system of social relationships in the present within which the production of meanings takes place..$^{33}$ Below, we briefly comment on the basic components of the Los Roques archaeology workshops.

Preparatory activities. In 1996 and 2001-2005, the first two listed authors organized six five-day educational trips of broad scope to Dos Mosquises Island for students from two Caracas high schools. These trips laid the foundation in both educational and logistical terms for later workshops. In 2007, several months before the first workshop, we gave the already-mentioned series of archaeology-related talks at the Gran Roque school. Several weeks beforehand, communication flowed between the two archaeologists and school authorities on several topics: the content and timetable of on-site daily activities, logistical support from the students' parents, menus, and a list of things for the students to bring. Upon arrival at Boca de Sebastopol, the site of the first workshop, each participant received copies of specially prepared texts and articles on Los Roques archaeology as well as a notebook, pad of paper, and writing and drawing implements. Students were encouraged to write and draw anything they wished; however, this was not obligatory. Following lunchtimes dedicated to the sharing of experiences amid general conversation, they were encouraged - though again, not obliged - to share their drawings and diary extracts with their peers.

Site selection criteria. The first workshop was carried out in Boca de Sebastopol in 2007. A few months before, a couple of Los Roques schoolchildren accompanied by

50 P.L. Jeppson, G. Brauer, 'Hey...', p. 83.

51 Y. Paz, 'Community..., p. 36.

52 P.B. Potter Jr., 'The Archaeological Site as an Interpretive Environment' in B.J. Little (ed.), Public Benefits of Archaeology, Gainesville 2002, p. 38.

53 Ch. Tilley, 'Archaeology as Socio-Political Action in the Present' in D.S. Whitley (ed.), Reader in Archaeological Theory; Post-Processual and Cognitive Approaches, London 1998, p. 308. 
a parent fortuitously had found some pre-Hispanic pottery and a figurine associated with the queen conch shellmidden in this remote and uninhabited part of the archipelago. The parent informed the archaeologists and at the first opportunity brought them to the site together with the children. The archaeologists recalled that as far back as 1983 they had inventoried this site as a low shellmidden covered by grasses and mangrove shrubs - but beyond the shells, had not observed any other remains attesting to human activity. The children's discovery changed the initial valuation of the site, and the archaeologists made an agreement with the children in which they promised to return to that location and all work together. This was the most logistically demanding of all the workshops as hundreds of kilograms of equipment, materials, tools, food and water had to be transported to the site by boat. An entire camp with kitchen, dining, sleeping areas and other facilities had to be erected (later to be dismantled and the site thoroughly cleaned up).

The second workshop took place on Gran Roque Island in 2009. It concentrated on a pre-Hispanic site partially excavated in the 1980s. The site lay next to the island's landing strip, the threatened expansion of which caused us to take action. The third workshop of 2011 on Krasky Island also featured a site where excavation had begun over a quarter of a century before, in this case 1983 . Here, the threat of the site's destruction due to expansion of the local settlement was worrying; meanwhile, the whole area was covered with modern rubbish. The potential for engaging the local population existed, and as a result not only students but also some local fishermen participated in daily excavation. The fourth workshop took place on Dos Mosquises Island in 2012. Students worked on a part of the periphery of what was already the most extensively and systematically excavated site in the entire archipelago. The archaeologists hypothesized that superficial strata of this peripheral area could have been affected by work on a landing strip carried out in the 1960s. The workshop aimed, therefore, at ascertaining the precise status of this portion of the site. A second goal was strengthening preexisting links between the Gran Roque community and the Dos Mosquises Biology Station.

To date, all workshops have focused on pre-Hispanic sites. Future plans, however, include colonial and republican locations. In contrast to the mainland, these are much rarer in Los Roques than pre-Hispanic sites.

Student selection criteria. All workshop participants (16 in two groups of eight) were selected by school authorities. Their ages ranged from 12 to 18 . Four criteria were applied as the workshops progressed: age; those most interested and motivated by the subject area; the institutions' top students; and the most cooperative ones in the daily life of the school. The most valuable group members proved to be, in our experience, those who beforehand had been the most enthusiastic about actively participating in the workshop experience. We recognize, however, that attaining ideal selection criteria is a complex matter when workshops figure as school extracurricular activities only and not components of the formal curriculum.

Group composition. Accompanying the 16 students were one or two schoolteachers and at least one parent representative. At almost all workshops, one or two boys 
from the first shift volunteered to work the next. Their role as guides to the newcomers was invaluable: nevertheless, on the following day, the youngest became fatigued and significantly less active than on the first shift. Interestingly, Yitzhak Paz, excavating with students in Israel, found that the oldest (15-16) evinced low motivation and efficiency while the youngest (8-9) displayed high motivation combined with low efficiency. He found the best combination of the two qualities in 11-12 year-olds, ${ }^{54}$ noting that with rare exceptions kids felt tired when they realized that excavation is characterized by hard work, attention and precision rather than entertainment. In contrast, our experience was that younger participants (10-14) were enthusiastic and physically robust while excavating but became tired during afternoon lectures and discussions. Only a few of the older students (15-18) became tired or distracted during excavation for the reasons alluded to by Paz, and the majority were very active during afternoon discussions.

Duration. Specific dates were established by school authorities according to their academic calendars. Each workshop lasted five days but required several weeks of preparation as well as time for post-workshop tasks. Part of the organizing team would arrive in Los Roques about 48 hours beforehand and stay about that long afterwards. After two and a half days (i.e., the workshop midpoint), the first group of students would overlap for lunch with the arriving second group. This enabled all to share experiences and socialize. In total, each group experienced four half-day sessions on the excavation site.

Professional assistance. Two archaeologists and three assistants supported each group of eight students in the first two workshops. In the last two, three archaeologists, two experienced assistants and two helpers brought the ratio of supervision to almost one-to-one.

Excavation goals and expectations. Professional standards and ethics in addition to the goals of the Los Roques excavations were explained to the participants while they were still in their classrooms. This information was reinforced during excavations and afternoon conferences. The specifics of any particular excavation episode were explained on site. Even though overall emphasis was placed not on scientific results but the process of interacting while excavating, the team of archaeologists and assistants strictly monitored respect for basic archaeological standards, methods and procedures. For example, maintaining uniform surfaces at every stratigraphic level proved a constant concern for the students; as a result, a good deal of the team's attention and help was dedicated to this issue. Similar experiences were pointed out by Yitzhak Paz. ${ }^{55}$ When, as in this case, an archaeology team aims at fulfilling educational and experiential needs while simultaneously upholding archaeological standards, the overall excavation process goes slowly, scientific results are proportionately few and the overall impact on the site is reduced. This phenomenon was also observed by Jeppson and Brauer. ${ }^{56}$ There

\footnotetext{
54 Y. Paz, 'Community..., pp. 40-41.

55 Ibid., p. 42.

56 P.L. Jeppson, G. Brauer, 'Hey..., p. 87.
} 
was no hurry on site in Los Roques because no fixed number of test pits or stratigraphic layers had to be completed during the workshops' excavation sessions. Students were free to interrupt their work to sit down and drink water as well as ask questions and call for the attention of the assistants when, for example, expertise was necessary to distinguish a piece of charred turtle bone from a fragment of burned shell. The students were involved not only in excavation but almost every activity on site. They carried tools, equipment and drinks; set up tarps and grids; lifted sand buckets from pits and trenches; screened soil; helped each other; documented artifacts in their contexts, including drawing and photographing them; categorized artifacts and ecofacts; and placed them in carefully labeled bags. In general, each group and each individual had the same opportunity to experience the same activities.

Excavation standards and procedures. Students were assigned in pairs to one-square-meter test pits. These were usually arranged diagonally, suggesting a bishop's available squares on a chessboard, in order to facilitate access and maneuverability. Excavation proceeded horizontally in layers of $20 \mathrm{~cm}$ each. Students worked with small trowels and brushes; soil was removed in buckets. All groups screened soil with a one-square-millimeter mesh. Students were required to consult with the archaeology team about each object to be placed in a plastic bag, and they participated in the process to correctly label such bags before they were registered by the archaeologists. They noted any stratigraphic level, object or feature that they considered ought to be recorded in the data recovery notes. But activities on site were not restricted to excavation. The students helped select test pit locations and the directions of trenches. They were involved in all estimates and measurements. In fact they were constantly encouraged to observe, question, and engage in everything happening on site. By feeling tired, thirsty, dirty, sweaty, and stung by mosquitoes; meanwhile receiving the thoughtful guidance of archaeologists and their assistants; thereby experiencing the excitement of hard-earned and genuine contact with the past - participants had every opportunity to understand that archaeology is not a treasure hunt but a responsible research process. ${ }^{57}$

Excavating archaeological contexts. When a group of artifacts or features appeared in the soil matrix of a test pit, the students working there did not stop and hand off their trowels and brushes to the archaeologists. They were instead encouraged to unearth the context by themselves (under careful supervision), even if the process was extremely slow and students from other pits were leaving their own work to crowd around them. Those moments when everyone watched with bated breath the slow movements of brushes on gray-surfaced pottery vessels, or when the faces of human figurines began to emerge from the sand, were among the most vital and memorable experiences the workshops provided to students and archaeology team members alike. Indeed, what a fine way it proved to convey the meaning of the difference between a haphazard extraction of archaeological objects and the careful uncovering and documenting of an archaeological context in which the objects are only a part. Directing attention not primarily to objects but contexts is one of the best ways to undermine the values that

57 Ibid., p. 86. 
drive looting and to fight the widespread notion of archaeology as treasure hunting. Nevertheless, we recognize that at the moment of discovery of either contexts or whole objects, other methods are possible..$^{58}$

Off-site activities. Every evening, presentations in Power Point were offered on archaeological standards, procedures, and ethics as well as on the archaeologists' knowledge of the local past. The children learned new vocabulary, critical thinking skills, and professional values. They also learned to experience the holistic reality of archaeological sites by physically, intellectually, emotionally and imaginatively engaging with their surroundings in a new way: inviting past objects, features and sites to live anew and act on them. At the same time, participants were taught about cultural diversity and notions of change over time. The afternoon discussions often revolved around the similarities and differences among the lives of Amerindians, colonial period people and present-day inhabitants of the archipelago. ${ }^{59}$ Interestingly, the greatest empathy with people of the past arose when discussions turned to methods of exploitation and consumption of the natural resources of the archipelago such as queen conch, turtles, lobsters, reef fish and salt-all resources well known to the children today. Here we perceive an opening to explore connections between aspects of historical ecology and sustainable exploitation of local resources today ${ }^{60}$ The above confirms the realization of Anders Högberg that children chose to interpret the archaeological material not on the basis of archaeological source material and problems, but on the basis of contemporary events and experiences. ${ }^{61}$

The presentations and discussions with the schoolchildren also emphasized two intertwined aspects of archaeological research. The first is that the past does not emerge self-evident in unearthed objects and features; instead these provide only a basis, a starting point for a rigorous creation of the past in the present. Second, although conclusions about the fascinating Los Roques pre-Hispanic figurines were overtly provided, once again more attention was directed to the interpretive process and the contemporary intellectual contexts that inevitably shape interpretations at any given time.

58 Y. Paz, 'Community..., p. 42.

59 P.L. Jeppson, G. Brauer, 'Hey..., pp. 84-85 for a similar approach.

60 See A.O. Debrot, G. van Buurt, A. Caballero, A. Antczak, 'A Historical Review of Records of the West Indian Manatee and the American Crocodile in the Dutch Antilles', Journal of Caribbean Science, Vol. 42, № 2 (2006), pp. 272-280; A. Antczak, J. Buitrago, M.M. Antczak, H. Guada, 'Contribution to the History of Marine Turtle Exploitation in Venezuela', Proceedings of the $59^{\text {th }}$ Gulf and Caribbean Fishery Institute Conference, Historical Perspectives for Gulf and Caribbean Fisheries Session, Belize City 2007, pp. 63-73; M.M. Antczak, A. Antczak, 'Between Food and Symbol: The Role of Marine Molluscs in the Late Pre-Hispanic North-Central Venezuela' in A. Antczak, R. Cipriani (eds.), Early Human Impact on Megamolluscs, Oxford 2008, pp. 231-245; D. Schapira, I. Montaño, A. Antczak, J.M. Posada, 'Using shell middens to assess effects of fishing on queen conch (Strombus gigas) populations in Los Roques Archipelago National Park, Venezuela', Marine Biology, Vol. 156, № 4 (2009), pp. 787-795.

61 A. Högberg, 'The Past is the Present - Prehistory and Preservation from a Children's Point of View', Public Archaeology, Vol. 6, № 1 (2007), p. 42. 
Examples of archaeological reasoning helped show the children why an otherwise haunting narrative of a Los Roques fisherman does not conform to material sources. The story was heard by the first two authors some 25 years ago on Fernando Island. The fisherman maintained that his grandfather saw Amerindians, who had come to Los Roques to exploit queen conch, return to the mainland in canoes replete with barrels full of salted queen conch meat. We interpreted this narrative as an attempt at appropriating part of the archaeological discourse in order to legitimize fishermen's right to the Amerindian past. The children were invited to critically analyze the narrative in the light of the archaeological evidence; consequently, many different accommodative propositions were discussed. At last they discovered by themselves that the narrative may relate to events which indeed could have occurred in the late 19th or early 20th century, but certainly not during pre-Hispanic times. Thus, the story may serve as a potentially valuable insight into 19th or early 20th century past events that otherwise are barely supported by archaeological or documentary sources. In this case, multivocality was seen as promoting complementary rather than antagonistic versions "from above" and "from below" regarding the past. ${ }^{62}$ The children understood that although archaeologists manage information resulting from methodical investigations of archaeological data, they have no ownership of interpretations of said information. As one consequence, it is not archaeologists but local people who decide their identity on the basis of the past. ${ }^{63}$

Scientific results. Concerns have been raised about whether community archaeology can produce meaningful scientific results. ${ }^{64}$ The scientific results of the Los Roques workshops, though not yet fully analyzed, are quantifiable and add new information to the already existing corpus of data. For example, in Sebastopol in 2007, a new Ocumaroid campsite was excavated. It provided a sound radiocarbon date and nearly 20 human pottery figurines, some recovered in interesting contextual associations. It is noteworthy that only one Ocumaroid campsite was previously known in the entire island group; it was situated on Domusky Norte Island, in the opposite corner of the archipelago. ${ }^{65}$ During the Gran Roque workshop in 2009, some (not yet concluded) analysis seemed to suggest that at least part of the Amerindian campsite there might have been occupied by Ocumaroid seamen; nevertheless, the bulk of discovered materials and data strengthen previous conclusions about this site. The excavation on Krasky Island in 2011 also provided confirmation of previous conclusions regarding this island's archaeological site. In addition, it made clear that human figurines recovered dur-

62 Ch Damm, 'Archaeology..., p. 81.

63 D.M. Cavalcante Gomes, 'Archaeology and Caboclo Populations in Amazonia: Regimes of Historical Transformation and the Dilemmas of Self-Representation' in C. Gnecco, P. Ayala (eds.), Indigenous Peoples and Archaeology in Latin America, Walnut Creek 2012, p. 309; G. Nicholas, J. Hollowell, 'Ethical Challenges to a Postcolonial Archaeology: The Legacy of Scientific Colonialism' in Y. Hamilakas and P. Duke (ed.), Archaeology and Capitalism. From Ethics to Politics, Walnut Creek 2007, pp. 59-83.

64 F. Simpson, H. Williams, 'Evaluating...'; Y. Paz, 'Community....'

65 M.M. Antczak, A. Antczak, Los Ídolos... 
ing the excavations in 1983 (though no more were found in 2011) were spatially clustered with respect to the overall area of the site. Finally, on Dos Mosquises in 2012 it was discovered that the work on the lot beside the landing strip, carried out years ago, did not alter any layer of the site as had been previously suspected. It is noteworthy that publication of the workshops' academic results is already planned.

Documentary films and the website. All workshops were filmed by professional documentalists who stayed for all or most of the durations of the events. They were present during almost all excavation sessions and also accompanied the children in their offsite activities. The children were invited to share their thoughts and anecdotes on camera as well as comment on any issue related to the workshop experience. They usually readily agreed to appear dirty and sweaty in scenes later projected publicly on Gran Roque. The documentary films of up to 20 minutes depict excavation, interviews with the archaeologists, participants and local community members, as well as recreational activities, common meals, and still more. Once concluded, films are presented to the Los Roques community in events traditionally organized together with the Fundación Científica Los Roques in the main plaza of the village. The UEA website presents basic information and images from each workshop and also hosts some of the documentary films. ${ }^{66}$

Funding and logistical help. The leading institution in the project is the Universidad Simón Bolívar. This public university partly financed some of the community archaeology activities through its dean of public outreach. So far, the main funding necessary to carry on the project in such a remote place has come from non-governmental agencies: a private bank, embassies, and international agencies. Logistical help has been provided by a local airline, the Los Roques Scientific Foundation, inn owners and parents of the participating children who help with boat transportation. Though the success of the community project did help create new funding sources, it did not help fund-raising for strictly academic research projects from public, private, national or international sources. ${ }^{67}$ Perhaps the latter is the result of the fact that we did not take advantage of our Community Archaeology Project to publicize our academic research needs ${ }^{68}$

Follow-up activities. The activity immediately following every workshop is the sharing of experiences and information between the participants and their schoolmates through poster sessions and talks coordinated by teachers and school authorities. The children, however, also communicate their experiences beyond the classroom to families, neighbors and friends. A few months after the workshops, selected groups of workshop participants (six children and two teachers) are invited on a three-day visit to the Archaeology Research Unit lab at the USB in Caracas (thus far, visits have followed the first and fourth workshops). The visitors participate in a series of activities includ-

66 See <http://www.arqueologiausb.org>, 28 October 2012.

67 See Y. Paz, 'Community..., p. 23, for a similar experience in Israel.

68 P.L. Jeppson, 'Doing Our Homework: Reconsidering What Archaeology Has to Offer Schools' in M.J. Stottman (ed.), Archaeologists as Activists. Can Archaeologists Change the World?, Tuscaloosa 2010, p. 63. 
ing washing, sorting, labeling, drawing, identifying, storing, consolidating and analyzing the materials they helped excavate. Some formal talks on archaeological themes are given and there is also ample time for discussion, questions, walking through the university facilities, and sharing meals together.

\section{CONCLUDING REMARKS AND FUTURE PROSPECTS}

Because the Los Roques Community Archaeology Project is ongoing and embodied within a dynamically changing political, social and economic context, it is difficult to discuss conclusions. It is also important to emphasize at this juncture that the context alluded to above impacts both the archaeologists and the community. Thus the vicissitudes of the project are not solely due to the availability of funding. Nevertheless, we acknowledge that through the years the project has fostered an interest in the archaeological past among the community and activated its concern for the local cultural heritage. This interest is manifest in the increasingly active role played by the schoolchildren, teachers, fishermen, boatmen, and tourism operators, among others, in past-oriented activities.

Let us mention here a few evocative gestures of the community members: volunteering to contribute to the maintenance of the Dos Mosquises archaeological stop-over; offering to assist with the logistics of future workshops and the search for signs of past human activity in remote and still poorly surveyed parts of the archipelago; and donating colonial artifacts found accidentally by fishermen as a contribution to the future local museum or heritage center. The interest in creating a local association concerned with archaeological heritage issues is an encouraging initiative. Also thanks to the active and judicious engagement of community members, two new pre-Hispanic sites were discovered. The conjoined survey and eventual excavation of these sites is planned. The sense of ownership of the past and pride engendered by the project can be seen in the incorporation of the references to the pre-Hispanic past into the Los Roques Archipelago National Park anthem ${ }^{69}$ and the paintings of figurines executed by the children on their school walls. It is also rewarding to listen to the comments made by children during their interviews for the documentary films. All the above attests to the range of results that the insertion of the past into the present of the Los Roques community has produced. However, no less evocative are the calls and SMS messages that the team of archaeologists receives from children and adults in which they enquire about forthcoming activities and warn of potential threats to certain archaeological sites. This latter information is especially valuable as sustained site protection cannot be achieved without the interest and active support of local communities, especially on the Los Roques islands located so far from the administrative center of the country. Here, one of the future tasks is obvious: creating a functional matrix of heritage custo-

69 Himno de Los Roques, video file retrieved from <http://www.youtube.com/watch?v=ytqJsSu6V7g >, 28 October 2012. 
dians in which the local custodians (roqueños, who are not a descendant community but reside close to the archaeological sites), the professional custodians (institutions empowered by the central government to manage heritage, in this case the Instituto de Patrimonio Cultural), and the archaeologists ${ }^{70}$ will work together. The Instituto Nacional de Parques, the administrator of the Los Roques Archipelago National Park, should also be included in such an alliance. We are cognizant of the fact that the long-term effects of the project have yet to be measured and critically evaluated. But this will occur with the inclusion of the views of community members who may have their own ideas about this project's strengths and weaknesses - ideas not necessarily coincident with our own.

Our digging together with children causes frowns amongst some of our colleague archaeologists, as if doing so inevitably leads to looting and vandalism. Indeed, it is possible that some children would, if they could, dig without professional assistance. However, based on our experience, the final benefits of even these exceptional situations by far outweigh the eventual costs. ${ }^{71}$ Soon after the first Los Roques workshop, we confronted a case in which a couple of boys returned to the site alone and extracted from it some archaeological material. We also had a case of a new teacher (not a participant in the workshops) coming with her class to "excavate" in one of the sites already known to the archaeologists. In both cases, however, the damage to the archaeological sites was minimal while the social benefit of rectification was enormous. The above-mentioned two boys were persuaded by the school authorities to return the materials to the archaeologists. They were then reincorporated into the workshop community, and since then have become two of its best assets. The teacher, after conversation with the archaeologists, understood their argument. She returned to her class and explained why what she and they were doing was not proper with respect to the other schoolchildren involved in the Community Archaeology Project, the archaeologists, and their common heritage of Venezuelans. Both cases ultimately helped everyone gain a better understanding and appreciation of what archaeologists do and why they do it. And both raised awareness of the importance of protecting the local cultural heritage.

There are three main tasks on which the archaeology team would like to focus in the future. The first is the materialization of an almost 30-year-old, and very dear to us, idea: namely, the creation of a museum, ecomuseum or local heritage centre on Los Roques. The pace of this process depends entirely on the maturation of the local community in actively participating in its inception and design as well as in assuming its future self-sustaining operation and maintenance. As demonstrated in the volume on Archaeological Site Museums in Latin America, ${ }^{72}$ such a museum would certainly en-

70 P. Taruvinga, 'Comments on Chirikure, S. \& G. Pwiti (2008): Community Involvement in Archaeology and Cultural Heritage Management: An Assessment from Case Studies in Southern Africa and Elsewhere', Current Anthropology, Vol. 49, No. 3 (2008), p. 480.

71 See also P.L. Jeppson, G. Brauer, 'Hey..., pp. 82-83.

72 H. Silverman (ed.), Archaeological... 
hance archaeological heritage diffusion, protection and management while providing a point of interest for local tourism. However, it is clear that responsible long-term involvement of the community is key to the success of such an idea. Several museum-related topics have already been discussed with members of the local community. For example, issues such as what the logo of the museum should be and how the museum should appear from an architectural point of view have already been preliminarily discussed. Community members have even executed some detailed sketches of the future museum. Also, a network of heritage trails closely related to the museum was creatively debated during the workshop organized for tourism operators. In addition, parameters related to pottery workshops in which some of the community members would learn to manufacture replicas inspired by local archaeological originals were amply discussed. These objects would be sold in the museum and local souvenir shops, economically benefit the local community, and provide an alternative to the majority of souvenirs currently offered to tourists. ${ }^{73}$ One exceptionally encouraging experience related to the future museum was linked to the following circumstance: since 2002 we had been unable to find the institutional patronage or funding necessary for the maintenance and increasingly urgent repairs of the Archaeological Stop-Over on Dos Mosquises Island. However, some Los Roques community members came forward to volunteer their assistance in this matter.

The second important task for the archaeology team is to work more closely with the Gran Roque school authorities and teachers to find a way of incorporating archaeology into the local school curriculum. Workshops implement principles of experiential archaeology, as we have deemed it, which archaeologists in other settings can apply to meet the multi-faceted needs of schoolchildren in circumstances far removed from classroom routine. We expect, however, that it is in the classroom where archaeology "as education" will meet the needs of the archaeology profession. ${ }^{74}$ Two major benefits derived from archaeology can be attained in classrooms: the associative benefits of heritage and the knowledge benefits of history. ${ }^{75}$ Coordinated efforts by archaeologists and teachers in Los Roques classrooms are necessary to effect better contextualization of the workshop excavations. This will enable children to engage a whole range of general and local archaeology-related topics, including issues related to the level of commitment and responsibility required in the profession through instruction that involves ethics and standards. ${ }^{76}$ Opportunities should also be found to properly address the multiple links between the marine, scenic and historical-cultural resources that converge in the uniqueness of the cultural landscape of this archipelago. Additionally, our experience tells us that aspects of historical ecology are among the subjects most avidly absorbed

73 S. Moser, D. Glazier, J.E. Phillips, L. Nasser el Nemr, S. Mousa, M. Nasr Aiesh, R.S. Richardson, A. Conner, M. Seymour, 'Transforming..., p. 241.

74 P.L. Jeppson, G. Brauer, 'Hey..., p. 85.

75 F.P. McManamon, 'Heritage, History, and Archaeological Educators' in B.J. Little (ed.), Public Benefits of Archaeology, Gainesville 2002, p. 31.

76 P.L. Jeppson, G. Brauer, 'Hey..., p. 85. 
by the Los Roques schoolchildren. It is to be hoped that initiatives in all the above areas will conduce to the emergence of home-grown Los Roques archaeologists.

The third task relates to the evolution of the workshops with schoolchildren. Through the years, it has become increasingly clear to us that a proper understanding of the youths' mental grasp of the past and its articulation with the present is vital to the success of any archaeology-related effort directed towards them. Our experience therefore accords with the realizations of Peter Stone ${ }^{77}$ : what children want to know about the past is what is central to them in the present. Similarly, Anders Högberg, digging with 11-year-olds in Sweden, concluded that children want to preserve something close, something they are emotionally attached to rather than have an intellectual relationship with [that entity].$^{78}$ For example in Högberg's experience, the places that the children wanted to preserve for the future were selected more on the basis of their feelings for - and relationships associated with - those places than on the physical distinctiveness of such locales. Clearly, immaterial aspects carried more weight for these children than material ones. Högberg went further, considering that for 11-year-olds the past is completely merged with the present. That is, the past is in the present or the past does not exist at all, things just exist in the present..$^{79}$ Consequently, the only manifestation of the past is the present.

Drawing from the above, we may reasonably surmise that formally instructing young people about the past is not enough. We need to engross them in archaeological objects, features and sites, making the present more visible by juxtaposing it with the past through its remains. ${ }^{80}$ We need to foster personally significant relationships with these things, as well as multisensorial experiences flowing from being in their midst in current time. But this is not all that is in play here. Simultaneously, the workshops immersed participants in "a heterogeneous mix of humans and things" or in a blended flow of matter, energy and information that Ian Hodder defined as an "entanglement" ${ }^{11}$ The workshop ambiance is therefore a dynamic set of four interlinked dependencies: between students and their own group, between students and the archaeology team, between students and the surrounding "things" (including artifacts, ecofacts and features from both the past and present), and between everyone and the surrounding landscape and weather. Not only hard material entities but immaterial thoughts, ideas, emotions, feelings, sounds, and words contribute to the embrace of the on-site workshop. ${ }^{82}$ Smells, shapes, and the

77 P.G. Stone, 'The re-display of the Alexander Keiller Museum, Avebury, and the National Curriculum in England' in P.G. Stone, B.L. Molineaux (eds.), The Presented Past: Heritage, museums and education, London-New York 1994, p. 195.

78 A. Högberg, 'The Past...', p. 41.

79 Ibid., p. 42.

80 M. Foucault, 'Nietzsche, genealogy and history' in D. Bouchard (ed.), Language, Counter-Memory, Practice Ithaca 1977 cited in L. Meskell, Archaeologies of Social Life. Age, Sex, Class et cetera in Ancient Egypt, Oxford 1999, p. 224.

81 I. Hodder, Entangled. An Archaeology of the Relationships between Humans and Things, Oxford 2012, pp. 105, 174.

82 Ibid., pp. 119, 219. 
weights of things further deepen the sensory complexity enveloping workshop participants. Clearly it is important to create a rich context for sensory and intersensorial experiences because meanings are conveyed through sensory shifts. ${ }^{83}$ Examples abound. One was the change from silent concentration, fatigue and drops of sweat on faces during an "ordinary" excavation session to shouts of joy and racing pulses when the solemn face of a human clay figurine slowly emerged from the sand. Another was the palpable softness and cleanliness of a tablecloth flapping in the breeze on a rustic camp dining table "in the middle of nowhere" contrasting with black mud filling the trenches after a menacing thunder-and-lightning storm during the night, the same storm that snapped tent lines and banished sleep. A third was the pungent odor of the salt marshes surrounding the excavation site mixing with the exciting smell of fried fish flooding the camp at dinnertime, whetting hunger. A fourth example of significant sensory impact was the students' silent struggle between sleepiness and curiosity during the evening talks while watching slides illuminate the sun-faded boards of a shanty wall. And a fifth was, no doubt, the smile and word of thanks when a colleague's helping hand suddenly appeared to help raise a heavy bucketful of sand. We may expect, then, that the richer and denser the sensory embrace of an on-site archaeology workshop, the harder it will be not to feel the tactile presence of the past at that very spot; and the more difficult it will be to disentangle that felt past from one's personal future. Nevertheless, the challenge lies in transforming just such swiftly passing impressions, feelings and emotions into material forms. We may think that the materialization of some of the above-mentioned immaterial and largely evanescent phenomena will occur by the very fact of the children's "being in the workshop" and having the hands-on, real-life experience of archaeological excavation. However, could this be no more than wishful thinking? Can the impermanent thoughts, ideas, sensations and emotions arising from experiential archaeology events have lasting effects on any particular child? Perhaps the four strands of experience can be converted into long-lasting memories; but can such memories then catalyze students to act in ways beneficial to themselves and their societies? Our concern here is transforming such phenomena into durable material forms that can "act back" and create more permanent human - thing and human - human interdependencies.

We the authors judge that we must connect the participants of our experiential archaeology workshops to our wide-ranging involvement with the adult social actors of the Los Roques Archipelago community. By tying these two commitments together, there will emerge a larger, more complex tapestry or entanglement - one we began to weave 30 years ago by inviting the ever-increasing participation of Los Roques community members. Working now to integrate both categories of social actors through community archaeology - reworking, mending, and improving their integration - will in the long run contribute to a greater and richer interdependence that may prove propitious ground for the translation of the immaterial and evanescent into the material and durable. Still, an important component of this interdependence is time. When, in

83 D. Howes, 'Scent, Sound and Synaesthesia: Intersensoriality and Material Culture Theory' in Ch.Y. Tilley, W. Keane, S. Kuchler, M. Rowlands, P. Spyer (eds.), Handbook of Material Culture, London 2006, p. 164. 
all likelihood, will this transformation take place? In this regard, many years ago we already adjusted our watches to the local time.

\section{ACKNOWLEDGEMENTS}

The authors would like to acknowledge the enthusiasm and professional assistance of Blanca Elena Machado (Fundación Científica Los Roques), Zulay Barrios (Escuela Educativa Bolivariana Los Roques), and the documentalists Miguel Yabrudez and Regulo Briceño and their assistants. Many thanks go to our assistants Daphne Oliveras, Oliver Antczak, Irene Montaño, Pavel Núñez, Franklin Vázquez and Armando Peña. Thanks go also to institutions and individuals who financed and helped organize the activities described in this paper: Universidad Simón Bolívar, Banesco Banco Universal, Fundación Científica Los Roques, Polish Embassy in Caracas (Polish Aid Program), French Embassy in Caracas, Alianza Francesa, Agencia Española de Cooperación Internacional (AECI), Corporación Andina de Fomento (CAF), Línea Aérea Aerotuy, and various hostel and inn-keepers, especially from the Gremary, La Gaviota, Ranchito Power, El Canto de la Ballena, Los Corales, Eva, La Laguna, and Grupo Caracol establishments. We are especially grateful to the Gran Roque school teachers and children for their help, enthusiasm and companionship. Special acknowledgements go to our Los Roques friends, especially Bernardo Mata (Pelón), Jesús Mata (Zapatón), Renzo Barbieri, Germán Olavarría, Toribio Mata, Germán Reyes (Moncho), Pablo Segundo Mata, Felipe Marcano (Lipe), Adei Mata, Luis Urbaez Marcano (Guayo), Félix Marcano, Jesús Contreras, and Teobaldo Salazar (Papa Tobaro) ( $t$ ), Felipe Narváez (Niole) ( $t$ ), and Amanda Marcano ( $t$ ). We acknowledge the permissions for our work issued by Instituto Nacional de Parques (Inparques) and Instituto del Patrimonio Cultural (IPC). We are grateful to Dan Bailey for valuable insights and observations on the manuscript of this paper.

\section{REFERENCES}

Altez Y., P. Rivas, Arqueología e historia de la parroquia Caruao, Caracas 2001.

Amend T., A. Antczak, M.M. Antczak, J.R. Delgado, H.J. Guada, B. Rodríguez, P. Vernet, Parque Nacional Archipiélago Los Roques, Caracas 1992.

Amodio E. (ed.), Historias de la antropología en Venezuela, Maracaibo 1998.

Antczak A., 'La pesca Prehispánica; El caso del sitio Dos Mosquises, Archipiélago de Los

Roques, Venezuela', Proceedings of the 14th International Congressfor Caribbean Archaeology, Barbados 1993.

Antczak A., Late Prehistoric Economy and Society of the Islands off the Coast of Venezuela: A Contextual Interpretation of the Non-Ceramic Evidence, Unpublished PhD Thesis, Institute of Archaeology, University College London, London 1999.

Antczak A., M.M. Antczak, 'La Esfera de Interacción Valencioide' in M.G. Arroyo, L. Blanco, E. Wagner (eds.), El Arte Prehispánico de Venezuela, Caracas 1999. 
Antczak A., M.M. Antczak, Los Mensajes Confiados a la Roca, Caracas 2007.

Antczak A., M.M. Antczak, 'Pre-Hispanic Fishery of the Queen Conch, Strombus gigas, on the Islands off the Coast of Venezuela' in P. Miloslavich, E. Klein (eds.), Caribbean Marine Biodiversity. The Known and the Unknown, Lancaster 2005.

Antczak A., J. Buitrago, M.M. Antczak, H. Guada, 'Contribution to the History of Marine Turtle Exploitation in Venezuela', Proceedings of the 59th Gulf and Caribbean Fishery Institute Conference, Historical Perspectives for Gulf and Caribbean Fisheries Session, Belize City 2007.

Antczak A., R. Cipriani (eds.), Early Human Impact on Megamolluscs, Oxford 2008.

Antczak A., J.M. Posada, M.M. Antczak, R. Cipriani, D. Schapira, I. Montaño, 'Early Human Impact on Queen Conch (Strombus gigas) in Venezuela' in A. Antczak, R. Cipriani (eds.), Early Human Impact on Megamolluscs, Oxford 2008.

Antczak M.M., Idols' in Exile: Making Sense of Prehistoric Human Pottery Figurines from Dos Mosquises Island, Los Roques Archipelago, Venezuela, Unpublished PhD Thesis, Institute of Archaeology, University College London, London 2000.

Antczak M.M., A. Antczak, 'Between Food and Symbol: The Role of Marine Molluscs in the Late Pre-Hispanic North-Central Venezuela' in A. Antczak, R. Cipriani (eds.), Early Human Impact on Megamolluscs, Oxford 2008.

Antczak M.M., A. Antczak, 'Distribution des établissements préhistoriques dans certaines íles du Vénézuéla in Civilisations Precolombiennes de la Caraïbe’, Paris 1989.

Antczak M.M., A. Antczak, 'Este faro sí era un faro bueno: El rescate del faro de la isla del Gran Roque', Tópicos, № 589 (1988).

Antczak M.M., A. Antczak, 'La Arqueología y los Arqueólogos; Los Aborígenes de las Islas Venezolanas' in A. Ojeda, P.G. Martínez (eds.), Educación Artística, $7^{\circ}$ Grado, Tercera Etapa, Educación Básica, Caracas 1988.

Antczak M.M., A. Antczak, 'La historia postcolombina de Los Roques: siglos 16-19', Tópicos, No 566 (1986).

Antczak M.M., A. Antczak, 'Las investigaciones arqueológicas en el Parque Nacional Archipiélago de Los Roques' in T. Amend, A. Antczak, M.J. Antczak, R.H. Delgado, J. Guada, B. Rodríguez, P. Vernet (eds.), Parque Nacional Archipiélago de Los Roques, Caracas 1992.

Antczak M.M., A. Antczak, Los Ídolos de las Islas Prometidas. Arqueología Prehispánica del Archipiélago de Los Roques, Caracas 2006.

Antczak M.M., A. Antczak, 'Their World in Clay: The Art of Pre-Hispanic Venezuela' in G. Griffin, M.M. Antczak, A. Antczak, S. Berti (eds.), Ancient American Art. Masterworks of the Pre-Columbian Era, 3500 BC-1532 AD, Milano 2011.

Atalay S., Community-Based Archaeology. Research with, by, and for Indigenous and Local Communities, Berkeley-Los Angeles 2012.

Bernbeck R., S. Pollock, 'The Political Economy of Archaeological Practice and the Production of Heritage in the Middle East' in L. Meskell, R.W. Preucel (eds.), A Companion to Social Archaeology, Oxford 2007.

Bosio G., Ecomuseo del Hombre Roqueño para la Isla Gran Roque, Unpublished Undergraduate Thesis, Universidad Simón Bolívar, Caracas 2008. 
Buitrago J., 'Attempts to protect hawksbills in a Venezuelan National Park', Marine Turtle Newsletter, № 14 (1980).

Cardona Machado H., 'Viejos Conceptos para un Nuevo Contexto: Aportes desde la Arqueología en Comunidades de la Costa Central Venezolana', Antípoda, Vol. 14 (2012).

Cavalcante Gomes D.M., 'Archaeology and Caboclo Populations in Amazonia: Regimes of Historical Transformation and the Dilemmas of Self-Representation' in C. Gnecco, P. Ayala (eds.), Indigenous Peoples and Archaeology in Latin America, Walnut Creek 2012.

Chirikure S., G. Pwiti, 'Community Involvement in Archaeology and Cultural Heritage Management: An Assessment from Case Studies in Southern Africa and Elsewhere', Current Anthropology, Vol. 49, № 3 (2008).

Damm Ch., 'Archaeology, Ethnohistory and Oral Traditions: Approaches to the Indigenous Past', Norwegian Archaeological Review, Vol. 38, № 2 (2005).

Damm Ch., 'Comments on S. Chirikure and G. Pwiti (2008). Community Involvement in Archaeology and Cultural Heritage Management: An Assessment from Case Studies in Southern Africa and Elsewhere', Current Anthropology, Vol. 49, № 3 (2008).

Damm Ch., 'Towards a Glocal Archaeology?', Reply to Comments on Ch. Damm (2005): 'Archaeology, Ethnohistory, and Oral Traditions: Approaches to the Indigenous Past', Norwegian Archaeological Review, Vol. 39, № 1 (2006).

Debrot A.O., G. van Buurt, A. Caballero, A. Antczak, 'A Historical Review of Records of the West Indian Manatee and the American Crocodile in the Dutch Antilles', Journal of Caribbean Science, Vol. 42, № 2 (2006).

Derry L., M. Malloy, Archaeologists and Local Communities, Washington, D.C. 2003.

Díaz Peña N., La colección arqueológica del Lago de Valencia. Documentación y nueva museología, Valencia 2006.

Faulkner N., 'Archaeology from below', Public Archaeology, Vol. 1, № 1 (2000).

Foucault M., 'Nietzsche, genealogy and history' in D. Bouchard (ed.), Language, Counter-Memory, Practice Ithaca 1977.

Funari P.P., A.N. Vieira de Oliveira, E. Tamanini, 'Archaeology to the Lay Public in Brazil: Three Experiences' in J.H. Jameson Jr., S. Baugher (eds.), Past Meets Present. Archaeologists Partnering with Museum Curators, Teachers and Community Groups, New York 2007.

Gassón R.E. Wagner, 'Los otros Vestigios de la Atlántida, o el surgimiento de la arqueología moderna en Venezuela y sus consecuencias' in Y. Freites, Y. Texera (eds.), Tiempos de Cambio. La ciencia en Venezuela 1936-1948, Caracas 1992.

González Casas L., O. Marín, 'Tiempos superpuestos: arquitectura moderna e “indigenismo” en obras emblemáticas de la Caracas de 1950’, Apuntes, Vol. 21, № 2 (2008).

González Hurtado G., Prioridades de investigación orientadas a mejorar la gestión ambiental del Parque Nacional Archipiélago Los Roques (PNALR), Unpublished Masters Thesis, Universidad Simón Bolívar, Caracas 2007.

Himno de Los Roques, video file retrieved from <http://www.youtube.com/watch?v= ytqJsSu6V7g>, 28 October 2012.

Hodder I., 'Archaeological Reflexivity and the "local” Voice', Anthropological Quarterly, Vol. 76, № 1 (2003). 
Hodder I., Entangled. An Archaeology of the Relationships between Humans and Things, Oxford 2012.

Hodder I., 'The "Social” in Archaeological Theory: An Historical and Contemporary Perspective' in L. Meskell, R.W. Preucel (eds.), A Companion to Social Archaeology, Oxford 2004.

Högberg A., 'The Past is the Present - Prehistory and Preservation from a Children's Point of View', Public Archaeology, Vol. 6, № 1 (2007).

Howes D., 'Scent, Sound and Synaesthesia: Intersensoriality and Material Culture Theory' in Ch.Y. Tilley, W. Keane, S. Kuchler, M. Rowlands, P. Spyer (eds.), Handbook of Material Culture, London 2006.

Hudson Ch., C. McEwan, 'Focusing Pride in the Past: Agua Blanca, Ecuador', Museum, Vol. 154, № 2 (1987).

Jeppson P.L., 'Doing Our Homework: Reconsidering What Archaeology Has to Offer Schools' in M.J. Stottman (ed.), Archaeologists as Activists. Can Archaeologists Change the World?, Tuscaloosa 2010.

Jeppson P.L., G. Brauer, 'Hey, Did You Hear about the Teacher Who Took the Class Out to Dig a Site? Some Common Misconceptions about Archaeology in Schools' in L. Derry, M. Malloy (eds.), Archaeologists and Local Communities. Partners in Exploring the Past, Washington 2003.

Little B.J., 'Archaeology as Shared Vision' in B.J. Little (ed.), Public Benefits of Archaeology, Gainesville 2002.

Mapunda B., P. Lane, 'Archaeology for Whose Interest - Archaeologists or the Locals?' in N. Merriman (ed.), Public Archaeology, London 2004.

Marshall Y., 'Community Archaeology' in B. Cunliffe, Ch. Gosden, R.A. Joyce (eds.), The Oxford Handbook of Archaeology, Oxford 2009.

Marshall Y., 'What is community archaeology?’, World Archaeology, Vol. 34, № 2 (2002).

McEwan C., M.I. Silva, Ch. Hudson, 'Using Past to Forge the Future: The Genesis of the Community Site Museum at Agua Blanca, Ecuador' in H. Silverman (ed.), Archaeological Site Museums in Latin America, Gainesville 2006.

McManamon F.P., 'Heritage, History, and Archaeological Educators' in B.J. Little (ed.), Public Benefits of Archaeology, Gainesville 2002.

Méndez Baamonde J., 'Aspectos de la geología marina en el Archipiélago de Los Roques', Memorias V Congreso Geológico Venezolano, Caracas 1977.

Meneses Pacheco L., G. Gordones Rojas, De la Arqueología en Venezuela y de las Colecciones Arqueológicas Venezolanas. Propuesta para la construcción de la Red de Museos de Historia de Venezuela, Caracas 2010.

Meneses Pacheco L., G. Gordones Rojas (eds.), La arqueología venezolana del nuevo milenio, Mérida 2001.

Merriman N., Public Archaeology, London 2004.

Meskell L., Archaeologies of Social Life. Age, Sex, Class et cetera in Ancient Egypt, Oxford 1999.

Morales Hidalgo Y., La Conservación Integral del Patrimonio Cultural Construido del Oriente Venezolano, Unpublished Doctoral Thesis, Universidad Central de Venezuela, Caracas 2011. 
Moser S., D. Glazier, J.E. Phillips, L. Nasser el Nemr, S. Mousa, M. Nasr Aiesh, R.S. Richardson, A. Conner, M. Seymour, 'Transforming archaeology through practice: strategies for collaborative archaeology and the community project at Quseir, Egypt', World Archaeology, Vol. 34 (2002).

Nicholas G., J. Hollowell, 'Ethical Challenges to a Postcolonial Archaeology: The Legacy of Scientific Colonialism' in Y. Hamilakas, P. Duke (eds.), Archaeology and Capitalism. From Ethics to Politics, Walnut Creek 2007.

Paz Y., 'Community Archaeology in Proto-Historical Tel Bareqet, Israel: School Children and Agency for Active Public Engagement in Cultural Heritage Projects', Public Archaeology, Vol. 9, № 1 (2010).

Posada J., B. Álvarez, J. González, 'Análisis del sistema pesquero del Parque Nacional Archipiélago de Los Roques', Memorias del Congreso Iberoamericano y del Caribe, Porlamar 1988.

Posada J.M., A.W. Stoner, K. Sullivan Sealey, A. Antczak, D. Schapira, R. Torres, I. Montano, M. Ray Culp, D. Aldana Aranda, Regional Initiative for the Evaluation of Queen Conch (Strombus gigas) Exploitation under an Historical Perspective, Paper presented at the 59th GCFI Institute Conference, Belize City 2006.

Potter Jr. P.B., 'The Archaeological Site as an Interpretive Environment' in B.J. Little (ed.), Public Benefits of Archaeology, Gainesville 2002.

Sajo-Bohus L., M.M. Antczak, E.D. Greaves, A. Antczak, J. Bermúdez, Zs. Kasztovszky, T. Poirier, A. Simonits, 'Incipient archaeometry in Venezuela: Provenance study of pre-Hispanic pottery figurines', Journal of Radioanalytical and Nuclear Chemistry, Vol. 265, № 2 (2005).

Sajo-Bojus L., M.M. Antczak, Zs. Kasztovszky, E.D. Greaves, A. Antczak, A. Simonits, D. Palacios, B. Millán, 'Neutron Activation Analysis of Pre-Columbian Pottery in Venezuela', Journal of Physics, Vol. 41 (2006).

Sanoja Obediente M., I. Vargas Arenas, La Revolución Bolivariana. Historia, Culturay Socialismo, Caracas 2008.

Schapira D., I. Montaño, A., Antczak, J.M. Posada, 'Using shell middens to assess effects of fishing on queen conch (Strombus gigas) populations in Los Roques Archipelago National Park, Venezuela', Marine Biology, Vol. 156, № 4 (2009).

Silverman H. (ed.), Archaeological Site Museums in Latin America, Gainesville 2006.

Simpson F., 'Community Archaeology under Scrutiny', Conservation and Management of Archaeological Sites, Vol. 10, № 1 (2008).

Simpson F., H. Williams, 'Evaluating Community Archaeology in the UK', Public Archaeology, Vol. 7, № 2 (2008).

Sociedad de Ciencias Naturales La Salle, El Archipiélago Los Roques y La Orchila, Caracas 1956.

Stone P.G., 'Presenting the Past: A Framework for Discussion' in J.H. Jameson Jr. (ed.), Presenting Archaeology to the Public. Digging for Truths, Lanham 1997.

Stone P.G., 'The re-display of the Alexander Keiller Museum, Avebury, and the National Curriculum in England' in P.G. Stone, B.L. Molineaux (eds.), The Presented Past. Heritage, museums and education, London-New York 1994. 
Stottman M.J. (ed.), Archaeologists as Activists: Can Archaeologists Change the World?, Tuscaloosa 2010.

Taruvinga P., 'Comments on Chirikure, S. \& G. Pwiti (2008): Community Involvement in Archaeology and Cultural Heritage Management: An Assessment from Case Studies in Southern Africa and Elsewhere', Current Anthropology, Vol. 49, № 3 (2008).

Tilley Ch., 'Archaeology as Socio-Political Action in the Present' in D.S. Whitley (ed.), Reader in Archaeological Theory; Post-Processual and Cognitive Approaches, London 1998.

Tully G., 'Community archaeology: general methods and standards of practice', Public Archaeology, Vol. 6, № 3 (2007).

Vargas Arenas I., Historia, identidad y poder, Caracas 1992.

Vargas Arenas I., 'Introducción al Estudio de las Ideas Antropológicas Venezolanas 1880-1936, Semestre Histórico, № 3 (1976).

Vila M.A., Aspectos Geopoliticos de las Dependencias Federales, Caracas 1967.

Wallace G., 'Archaeology and Society' in R.A. Bentley, H.D.G. Maschner, Ch. Chippindale (eds.), Handbook of Archaeological Theories, Lanham 2009.

Williams Trujillo W., Las Maravillosas Islas Venezolanas, Caracas 1980.

Young P.A., 'The Archaeologist as Storyteller' in B.J. Little (ed.), Public Benefits of Archaeology, Gainesville 2002.

Zulay Barrios M. (director of the local school on Gran Roque Island), personal communication, September 2012.

http://www.ipc.gob.ve/ipc, 29 October 2012.

http://www.arqueologiausb.org, 28 October 2012. 
Andrzej ANTCZAK, Received his Ph.D. in Prehistoric Archaeology from the Institute of Archaeology, University College London in 1999; previously studied Ethnography at Adam Mickiewicz University in Poznan, Poland and Anthropology at the Universidad Central de Venezuela. Currently, Professor at the Universidad Simón Bolívar in Caracas, Venezuela. With M. M. Antczak he funded and co-directs the Archaeology Research Unit at the same university. Since 1982 he has been co-directing (with M.M. Antczak) pioneering archaeological investigations on the off shore islands of the Venezuelan Caribbean. His recent books include: Los Idolos de las Islas Prometidas; Arqueología Prehispánica del Archipiélago de Los Roques (Editorial Equinoccio, 2006); Los Mensajes Confiados a la Roca (Editorial Equinoccio, 2007) (both co-authored with M.M. Antczak), and Early Human Impact on Megamolluscs (Archaeopress, 2008) (co-edited with R. Cipriani).

Maria Magdalena ANTCZAK, Ph.D. Institute of Archaeology, University College London 2000; anthropologist Central University of Venezuela, Caracas; studied ethnography at Adam Mickiewicz University, Poznan), is Professor of Anthropology and Archaeology at Simón Bolívar University in Caracas, co-founder and co-director (with A. Antczak) of the Archaeology Research Unit at the same university. Since 1982 she co-directed (with A. Antczak) pioneering archaeological investigations on the off shore islands of the Venezuelan Caribbean. Her academic interests include (re)construction of past social realities both in pre-Hispanic (island-mainland relations) and colonial north-central Venezuela, method and theory of meaning attribution and signifying practices applied to the study of representational material culture, using approaches of cognitive, symbolic and contextual archaeology. Her recent publications (with A. Antczak) include the monographs Los Ídolos de las Islas Prometidas: Arqueología Prehispánica del Archipiélago de Los Roques (2006); Los Mensajes Confiados a la Roca (2007) and Their World in Clay: The Art of Pre-Hispanic Venezuela, in Ancient American Art 3500 BC-AD 1532: Masterworks of the Pre-Columbian Era (2011).

Gustavo GONZALEZ HURTADO, studied Oceanography in La Salle Foundation of Natural Sciences and received his M.Sc. in Development and Environment in the Simón Bolivar University in Caracas in 2007. His interests focus on the social aspects of development and its impact on the natural and socio-cultural environment. Since 2007 has been a research associate at the Archaeological Research Unit of the same university, focusing on the social and community aspects of the projects carried out by the unit. He has participated in archaeology and archaeological community projects, and social and environmental management in the Los Roques Archipelago National Park and in the Los Testigos Archipelago.

Konrad A. ANTCZAK, M.A./Ph.D. research student in historical archaeology at the College of William \& Mary, Williamsburg, Virginia. He has long-term experience and interest in the 17th-19th century historical archaeology of the southern Caribbean. 


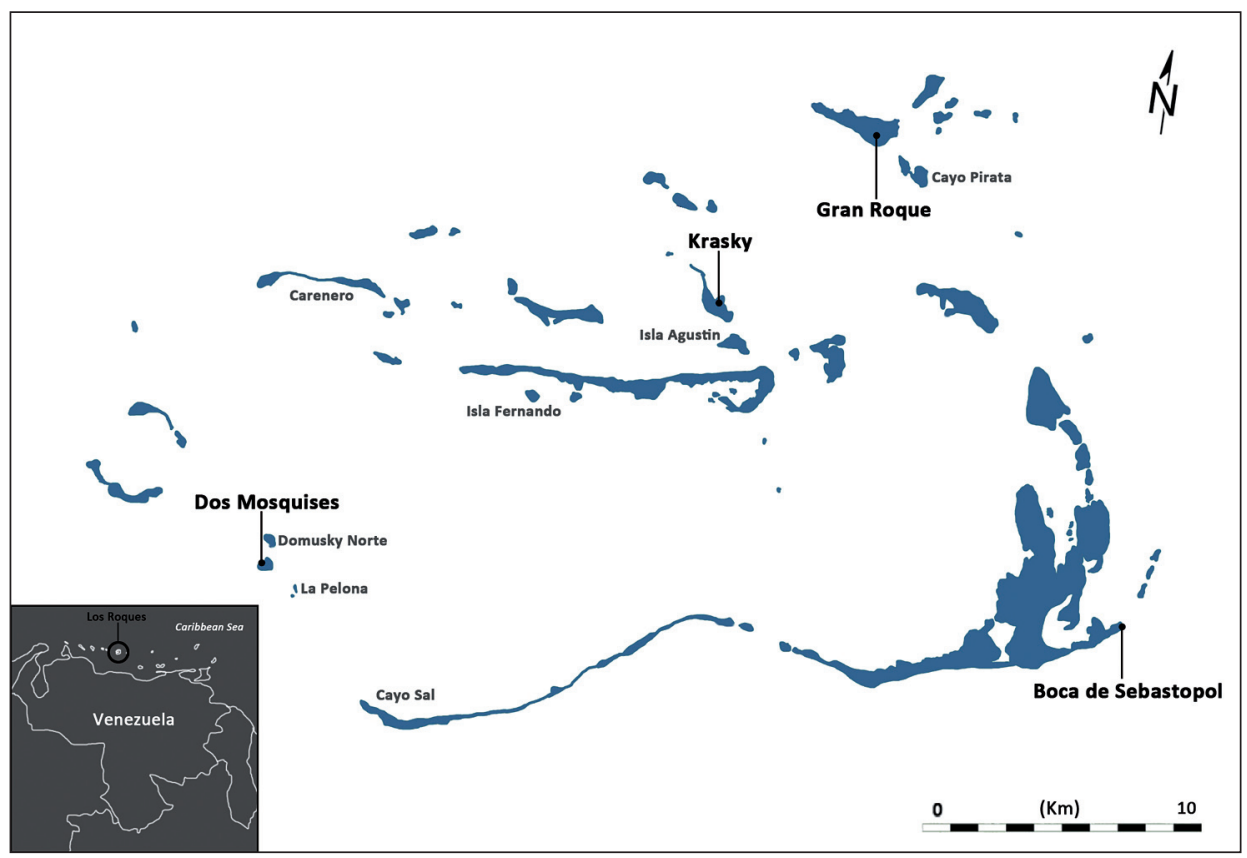

Figure 1. Map of the Los Roques Archipelago indicating the sites of the archaeology workshops discussed in the text

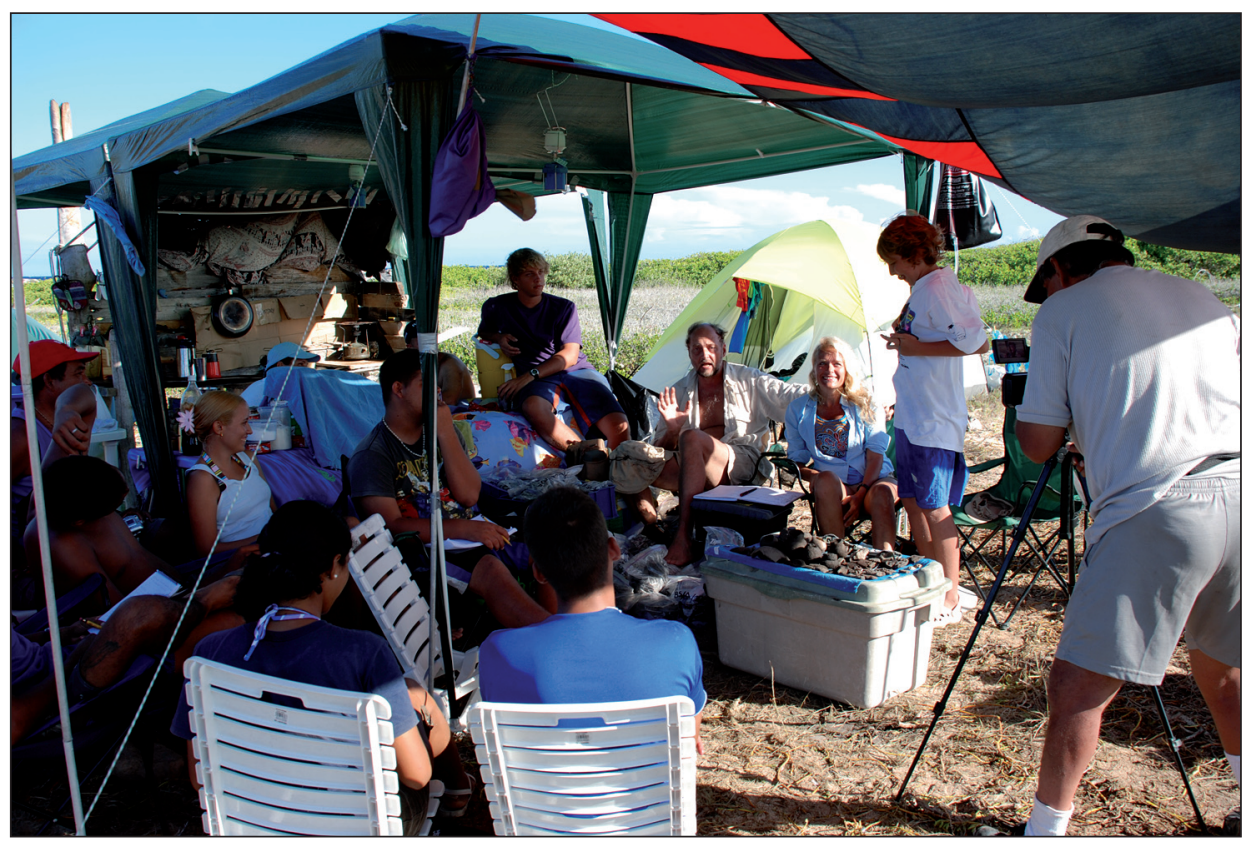

Figure 2. Boca de Sebastopol Archeological Workshop 2007 


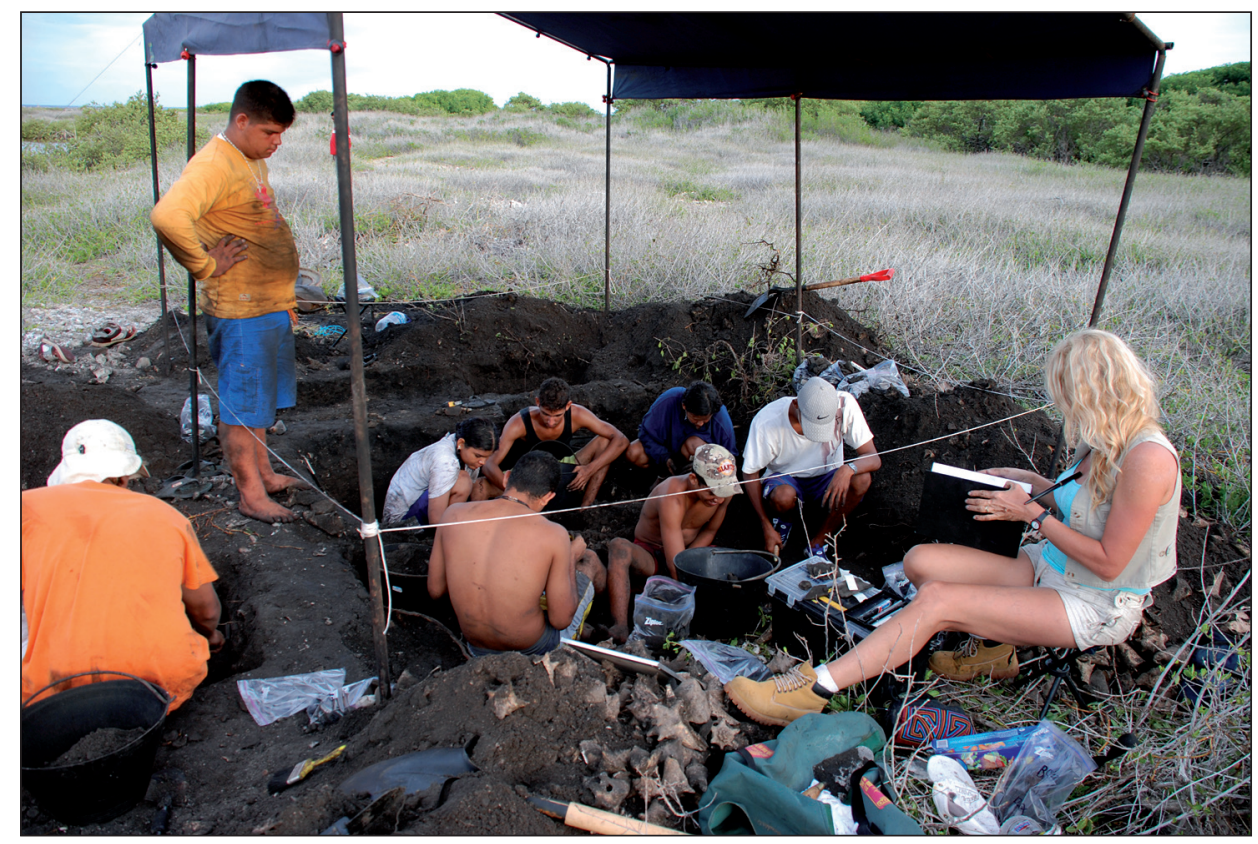

Figure 3. Boca de Sebastopol Archeological Workshop 2007

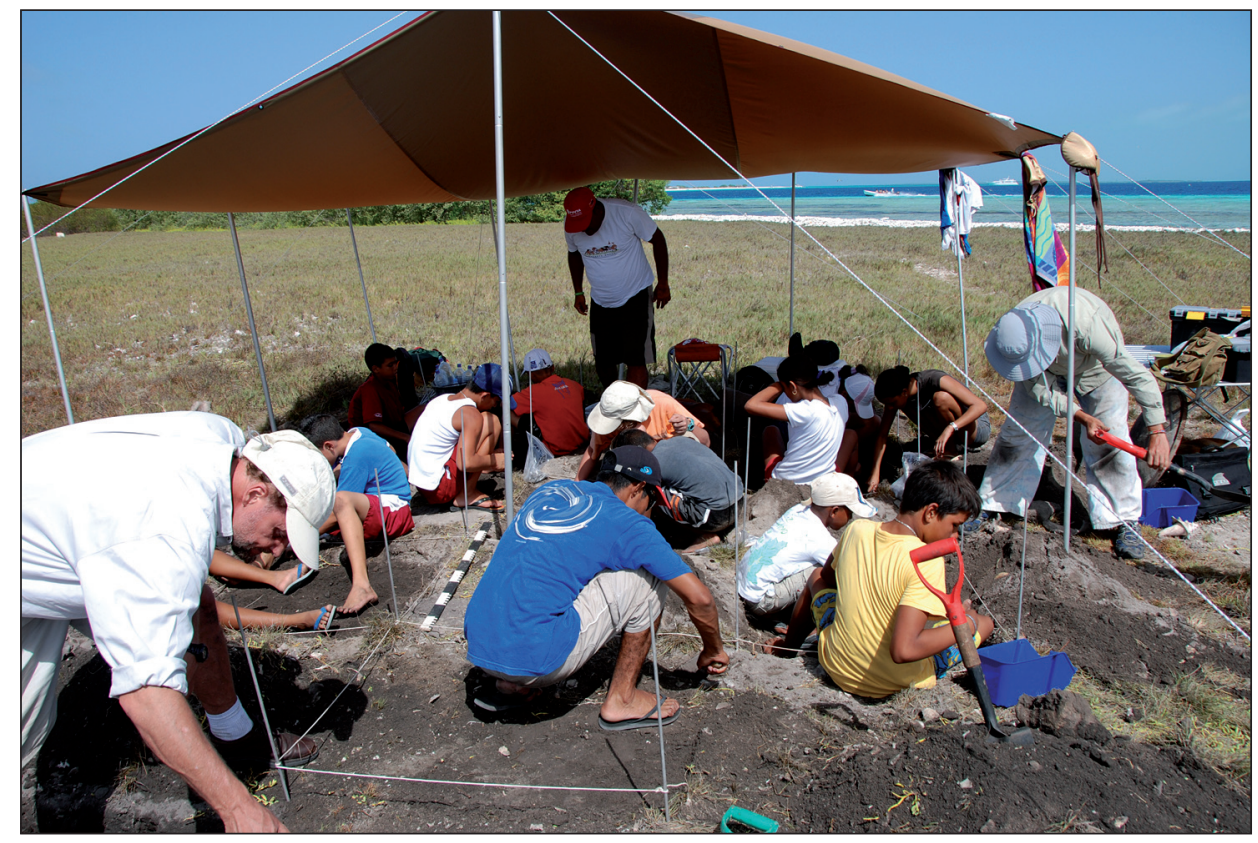

Figure 4. Gran Roque Archeological Workshop 2009 


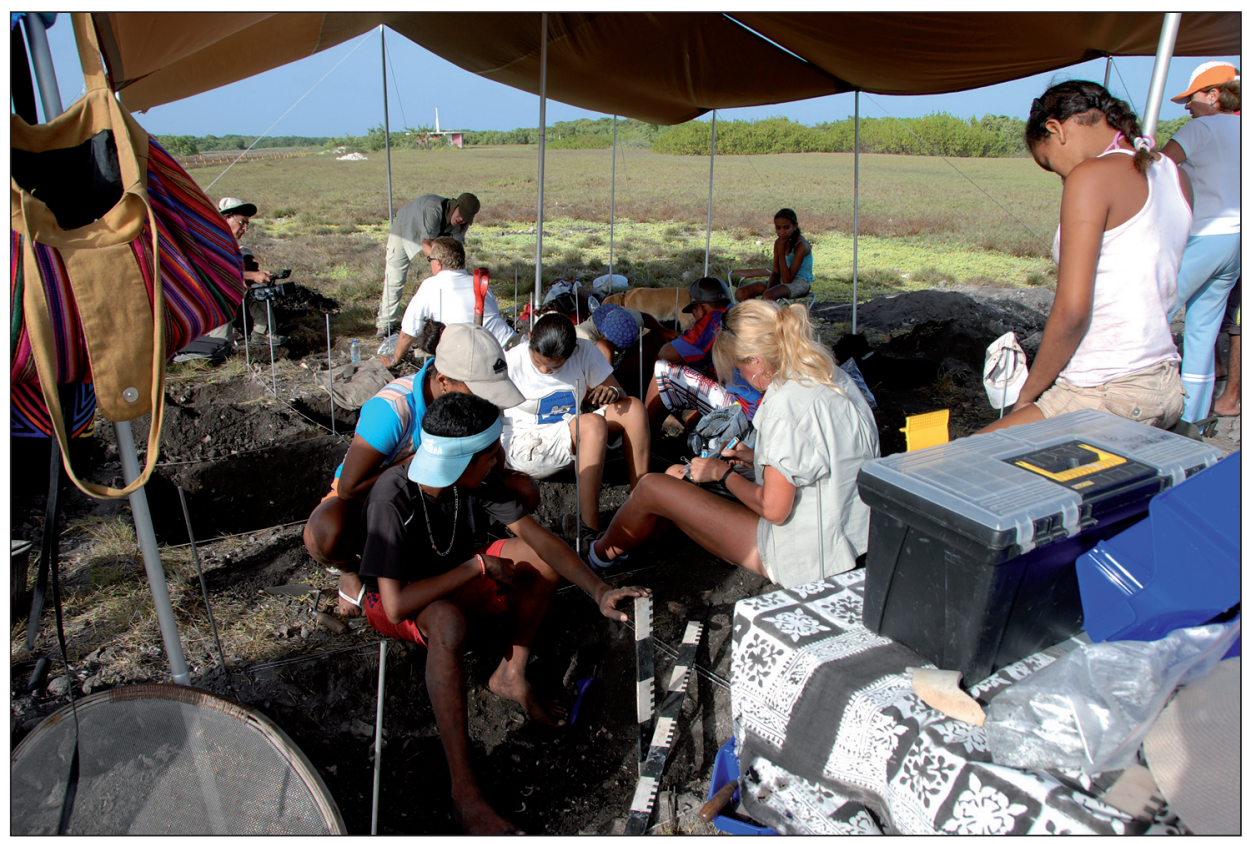

Figure 5. Gran Roque Archeological Workshop 2009

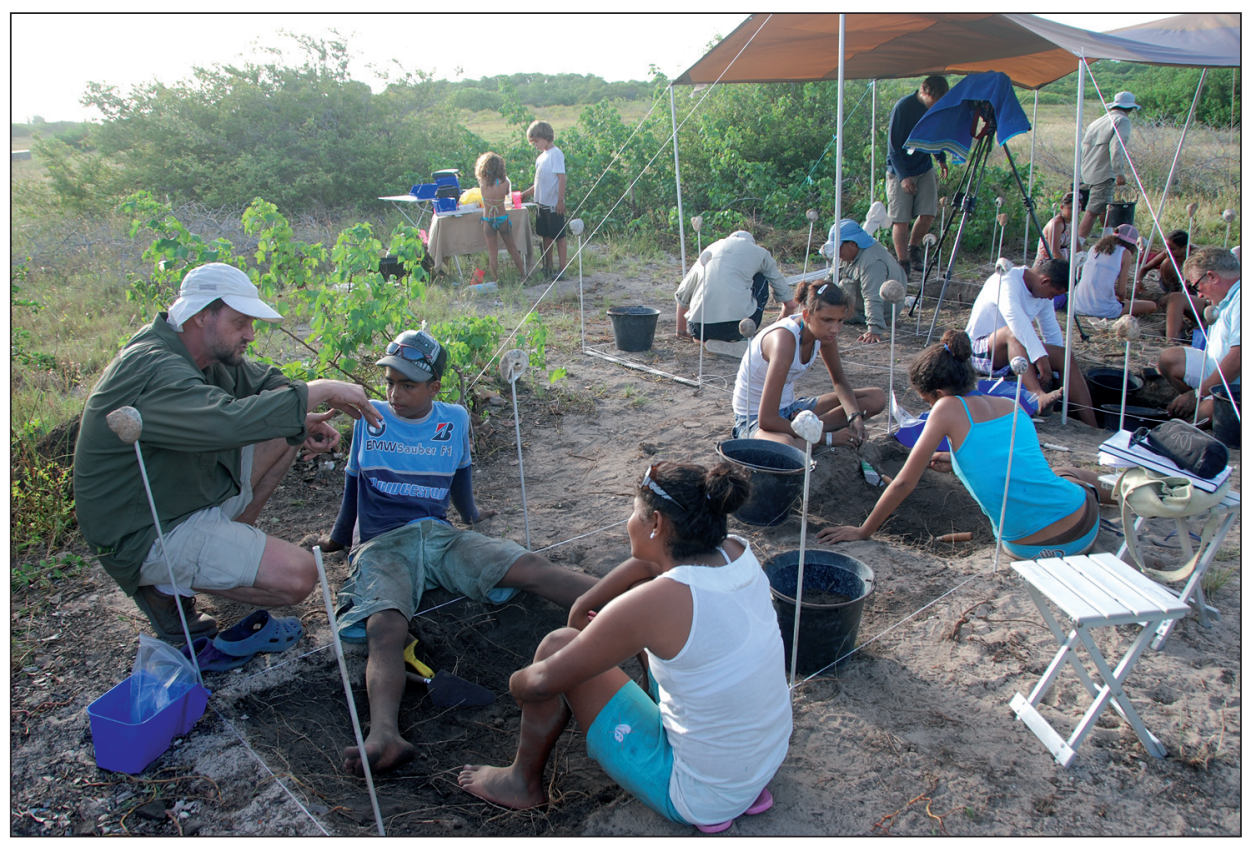

Figure 6. Krasky Archeological Workshop 2011 


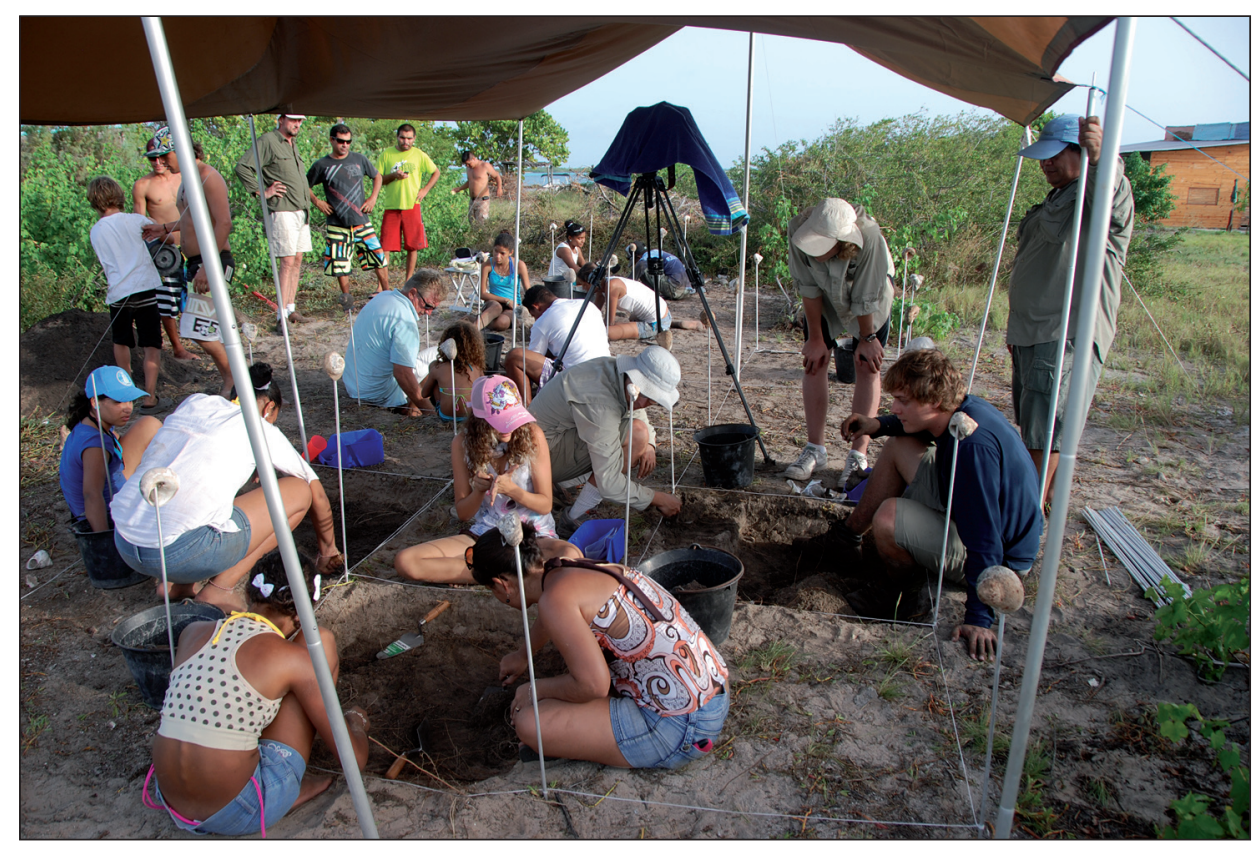

Figure 7. Krasky Archeological Workshop 2011

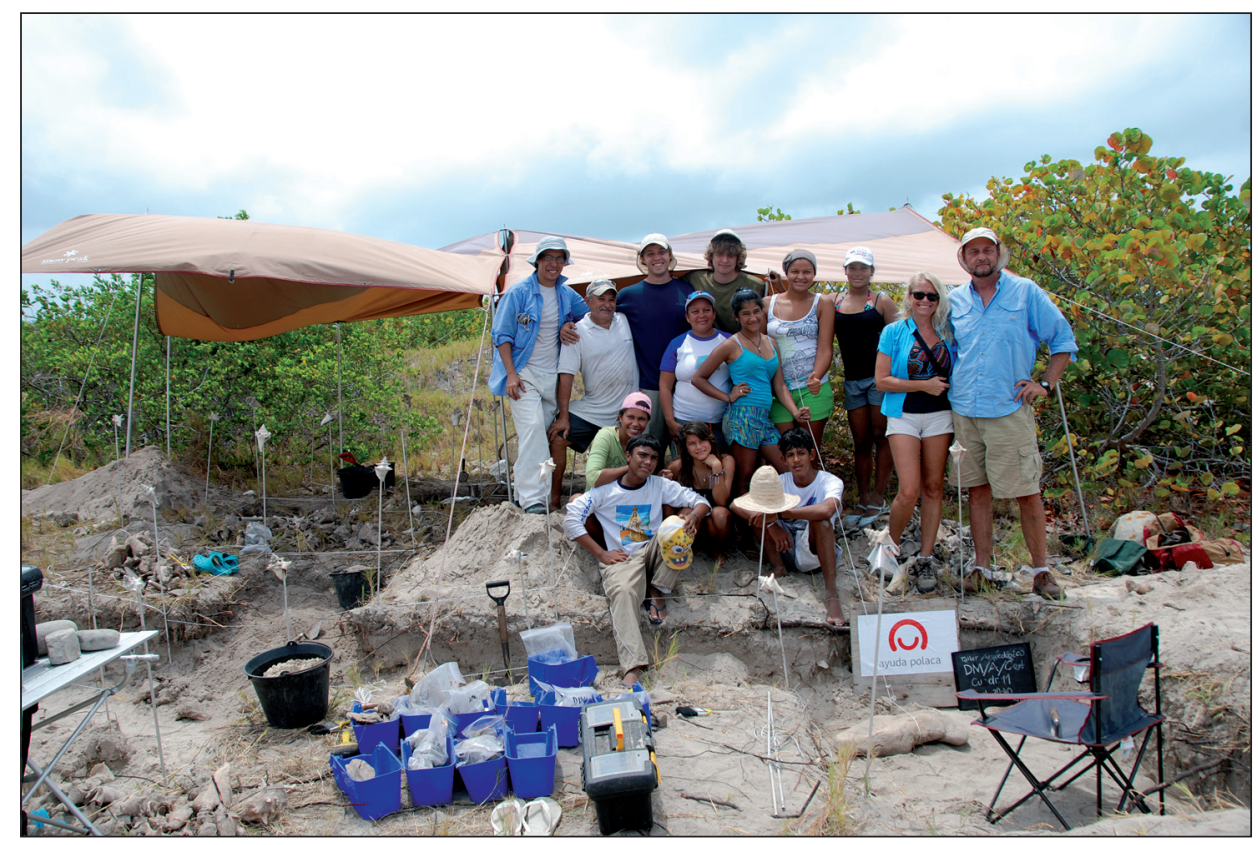

Figure 8. Dos Mosquises Archeological Workshop 2012 